\title{
Mortality of aircraft maintenance workers exposed to trichloroethylene and other hydrocarbons and chemicals: extended follow up
}

\author{
Larry Radican, $\mathrm{PhD}, \mathrm{MPH}^{1}$, Aaron Blair, $\mathrm{PhD}, \mathrm{MPH}^{2}$, Patricia Stewart, $\mathrm{PhD}^{2}$, and Daniel \\ Wartenberg, $\mathrm{PhD}^{3}$ \\ ${ }^{1}$ Global Outcomes Research and Health Technology Assessment, Merck \& Co., Inc. \\ ${ }^{2}$ Division of Cancer Epidemiology and Genetics, National Cancer Institute \\ ${ }^{3}$ Division of Environmental Epidemiology, Department of Environmental and Occupational \\ Medicine, University of Medicine and Dentistry of New Jersey - Robert Wood Johnson Medical \\ School
}

\begin{abstract}
Objective-To extend follow-up of 14,455 workers from 1990 to 2000, and evaluate mortality risk from exposure to trichloroethylene (TCE) and other chemicals.

Methods-Multivariable Cox models were used to estimate relative risk for exposed vs. unexposed workers based on previously developed exposure surrogates.

Results-Among TCE exposed workers, there was no statistically significant increased risk of allcause mortality $(R R=1.04)$ or death from all cancers $(R R=1.03)$. Exposure-response gradients for TCE were relatively flat and did not materially change since 1990 . Statistically significant excesses were found for several chemical exposure subgroups and causes, and were generally consistent with the previous follow up.
\end{abstract}

Conclusions-Patterns of mortality have not changed substantially since 1990 . While positive associations with several cancers were observed, and are consistent with the published literature, interpretation is limited due to the small numbers of events for specific exposures.

\section{Keywords}

trichloroethylene; TCE; hydrocarbons; solvents; cancer; mortality

\section{Introduction}

Over two decades ago the National Cancer Institute (NCI) assembled a cohort of civilian workers from the Hill Air Force Base in Utah to study risks associated with exposure to trichloroethylene (TCE) and other organic solvents and chemicals. ${ }^{1,2}$ Experimental $^{3}$ and some observational studies $^{4-6}$ suggest that organic solvents may increase the risk of certain cancers in humans. Currently, the only organic solvent classified as a human carcinogen is benzene, although others including trichloroethylene, perchloroethylene, chloroform and carbon tetrachloride are labeled as possible or probable carcinogens. ${ }^{3}$ In a 1998 study of the Hill Air Force Base cohort, which followed study subjects through 1990, several statistically significant

Corresponding author: Dr. Larry Radican Merck \& Co, Inc. One Merck Drive Whitehouse Station, New Jersey, 08889 Tel: 908-423-7558 Fax: 908-735-1688 larry_radican@merck.com. 
associations were reported between specific chemicals and causes of death; however, because of small numbers, lack of monotonic exposure-response gradients, and inconsistencies between genders, the findings were not conclusive. ${ }^{7}$ For TCE, no statistically significant associations for any specific cancer were reported.

In occupational cohort studies, the cancers most often linked to TCE are those of the liver and kidney and non-Hodgkin's lymphoma ${ }^{5,6}$ Some investigators have reported statistically significant increased risks for liver cancer, ${ }^{8-10}$ kidney cancer ${ }^{10-12}$ and non-Hodgkin's lymphoma,,${ }^{8,10,13}$ although others have not. ${ }^{14-17}$ Many of these studies report elevated but not statistically significant relative risks for various cancer sites, which makes elucidation difficult. Interpretation is further complicated because of the use of different study designs, exposure assessment techniques, reference groups, statistical methods and outcome measures (e.g., cancer incidence vs. mortality).

The inability to draw strong conclusions has fueled the debate as to whether or not TCE causes cancer. In this present study, we extend the follow up of the Hill Air Force Base cohort through 2000 to gain additional information about the health risks associated with workplace exposure to TCE and other solvents and chemicals.

\section{Methods}

Our study used data from two sources: a database on former civilian employees of the Hill Air Force Base in Utah, assembled by the National Cancer Institute (NCI), and mortality data from the National Death Index (NDI), administered by the Center for Disease Control and Prevention's National Center for Health Statistics (NCHS).

\section{Hill Air Force Base}

The Hill Air Force Base occupational cohort has been described in detail previously. 1,2,7 Briefly, in the early 1980s, the NCI assembled this cohort to study the mortality impact of occupational exposure to organic solvents, in particular, TCE. The cohort is composed of 14,455 civilians employed at this aircraft maintenance facility for at least one year between 1 January 1952 and 31 December 1956. Data on date of birth, race and gender and a complete work history at the base were extracted from the personnel records. Data were also collected from death records on the date and cause of death, which was coded according to the Eighth Revision of the International Classification of Diseases (ICDA-8).

\section{Exposure Assessment}

The exposure assessment that was carried out for this cohort study has been described in detail previously. ${ }^{2}$ In brief, information on exposures, chemicals, jobs, processes and other relevant information was collected from sources such as worker compensation files, histories and telephone books of the facility, organization charts, technical orders and position descriptions. Walk through surveys and interviews of long term employees were also conducted. Due to limited data linking historic air monitoring and chemical use with specific organizations (i.e., departments) and jobs, actual exposure levels for the cohort were not estimated. Therefore, exposure estimates (yes/no) to 21 solvents and chemicals were derived for each joborganization combination. The specific solvents evaluated were: TCE, 1,1,1-trichloroethane, methylene chloride, carbon tetrachloride, freon, isopropyl alcohol, acetone, toluene, methyl ethyl ketone, O-dichlorobenzene, perchloroethylene, chloroform, Stoddard solvent, and xylene. An exposure category called "any solvent" was created which was defined as exposure to one or more solvents. Other chemical exposures evaluated were styrene, JP4 gasoline, metal fumes/dust, silica, zinc chromate, nitroglycerine and solder flux. 
For TCE a more detailed approach was also taken that identified the frequency and pattern of exposure based on the job tasks. Intermittent or continuous exposure was assigned to subjects who used TCE infrequently or regularly, respectively, throughout the day. Low or peak exposure was assigned to subjects who used TCE for bench top work (to clean small parts) or who worked with vapor degreasers, respectively. Four categories of TCE were then developed for each worker: low intermittent, low continuous, peak infrequent and peak frequent. In addition, estimates of the frequency (times/day), duration (min/day) and intensity of TCE exposure (the latter as a score based on the limited measurement data) were developed. From these, a cumulative exposure score for TCE was developed for each subject in each job, summed across all jobs.

\section{National Death Index}

The NDI is a central computerized index of death record information for the entire US, beginning with deaths reported in $1979 .{ }^{18}$ The NDI Plus contains cause of death codes using the Ninth Revision of the International Classification of Diseases (ICD-9) for the years 19791998 and the Tenth Revision of the International Classification of Diseases (ICD-10) for 1999 and later.

\section{Data Analysis Matching of Data Files}

The cohort was matched to the NDI using available personal identifiers (i.e., name, social security number, gender, race and date of birth), to assess vital status between 1991 and 2000. The previous studies of the cohort by Spirtas et al. and Blair et al. reported on vital status through 1982 and 1990, respectively. 1,7

\section{Statistical Analysis}

We used a Cox proportional hazards regression model to estimate the relative risk, reported as a hazard ratio (HR) and 95\% confidence interval (CI), for various causes of death, for subjects exposed to specific solvents or chemicals, or any solvent, vs. those with no solvent and no chemical exposure. As recommended in the literature, we selected age as the time variable in the Cox model since disease and death rates usually change rapidly with age, and age effects should be controlled as precisely as possible. ${ }^{19,20} \mathrm{We}$ forced race and gender into the regression models and also ran separate analyses stratified by these two variables. In addition, we ran the multivariable Cox model stratified by 5-year calendar bands (<1955, 1956-1960, 1961-1965, etc., through 1996-2000) to assess the effects, if any, of calendar time.

Blair et al. ${ }^{7}$ used Poisson regression models in their follow up through 1990. The Poisson and Cox proportional hazards regression models are similar with the major difference being that the former usually has only a few strata where the latter creates a stratum for each case. ${ }^{20}$ To provide assurance that the hazard ratios from our Cox models could be compared validly to the rate ratios from the Poisson models for assessing changes in patterns of risk over time since the Blair et al. ${ }^{7}$ report, we first computed hazard ratios with the Cox model for the follow up through 1990 and compared them to the Poisson model rate ratios reported in Blair et al. ${ }^{7} \mathrm{We}$ ran two separate Cox models - the first for the white population only, so as to be directly comparable to the results reported by Blair et al., ${ }^{7}$ and the second for the entire cohort to assess whether inclusion of non-white subjects altered the overall results.

To evaluate exposure-response, we ran the Cox model with the TCE cumulative exposure score. ${ }^{2}$ For analysis, the score was categorized into tertiles: less than 5 unit-years, 5 to 25 unityears and greater than 25 unit-years. We also ran the model for the specific patterns of exposure that had been used in calculating the TCE cumulative exposure score: low exposure 
(intermittent, continuous) and peak exposure (infrequent, frequent). Such detailed exposure data were not available for the other chemicals used at the base, so analyses were done only for ever/never exposed for these chemicals.

For all analyses, a p-value $\leq 0.05$ was considered statistically significant.

\section{Ethical Review and Subject Confidentiality}

The study was reviewed and approved by the Institutional Review Boards at the University of Medicine and Dentistry of New Jersey - Robert Wood Johnson Medical School and the United States Air Force (USAF). Approvals/permissions were also obtained from the NCI and NDI, and the Hill Air Force Base Union was notified of the study. All personal identifiers within the final analytic datafile were deleted and destroyed prior to conducting statistical analyses to protect confidentiality.

\section{Software}

All statistical analyses were performed using SPSS statistical software, Version 11.0, developed by SPSS Inc., Chicago, Illinois.

\section{RESULTS}

The Hill Air Force Base cohort ( $\mathrm{n}=14,455)$ comprises 10,730 male $(74.2 \%)$ and 3,725 female subjects (25.8\%), of which 12,537 are white (86.7\%), 390 are non-white (2.7\%) and 1,528 are of unknown race $(10.6 \%)$. As in the previous studies of the cohort by Spirtas et al. ${ }^{1}$ and Blair et al., ${ }^{7}$ workers of unknown race were classified as white because those of known race were overwhelmingly white (97\%). As of 31 December 2000, 8,580 subjects had died and the mean age of the 5,875 $(40.6 \%)$ subjects still alive was $75(\mathrm{SD}=7)$. This represented an increase of 2,853 deaths over the 5,727 available for analysis in the 1990 follow up, a $50 \%$ increase. $^{7}$

Table 1 provides the results for TCE exposure for follow up through 1990, comparing the Poisson model rate ratios as reported by Blair et al. ${ }^{7}$ with our Cox model hazard ratios. To facilitate comparison, we report the hazard ratios for the 1990 follow up using one decimal place as was done with the rate ratios in Blair et al. ${ }^{7}$ Cox model 1 includes white subjects only (as in Blair et al. ${ }^{7}$ ) while Cox model 2 includes all races. It can be seen that the hazard ratios and $95 \%$ confidence intervals from the two Cox models using 1990 data are very similar to each other and to the Poisson model rate ratios and 95\% confidence intervals for most causes of death. Differences of at least 0.30 between the rate ratio and hazard ratio point estimates were observed for cancers of the esophagus, primary liver, cervix and kidney, and from bronchitis. These differences in point estimates, which could be attributable to either a slight variation in case definition or how the models handle small numbers of events across covariates, are minor when considered in the context of the wide confidence intervals. To account for calendar time as Blair et al. ${ }^{7}$ did, we ran analyses stratified by 5 -year calendar periods. Results were not statistically significant for most individual strata (data not shown). Due to the similarity of the Poisson and Cox model results for the 1990 follow up, we felt it was valid to compare our Cox model hazard ratios for 2000 to the Poisson model rate ratios for 1990 to assess changes in patterns of risk over time. Our Cox model results for all subjects were similar to the results for white subjects only and, therefore, we included all subjects in our analyses of follow up through 2000.

Table 1 also provides the results for follow up through 2000 (we report the hazard ratios using two decimal places for this and all subsequent analyses in this paper). It can be seen that none of the associations were statistically significant, although relative excesses of $50 \%$ or more were found for several causes of death: cancers of the esophagus, cervix and bone, and 
bronchitis. No statistically significant deficits occurred, but we did observe a comparably large reduced risk of death $(\mathrm{HR} \leq 0.70)$ among TCE exposed workers for leukemia and cancers of the stomach and rectum. Hazard ratios appeared similar for whites and non-whites; however, the point estimates were unstable for the latter subgroup due to small numbers and, therefore, it is not possible to draw any conclusions about mortality specifically in non-white subjects (data not shown).

Tables 2 and 3 provide hazard ratios for various causes of death, for overall exposure and stratified by tertiles of TCE cumulative exposure score, for men and women, respectively. The only statistically significant relative excess of death for overall exposure was from nonmalignant respiratory disease in men, showing a 30\% excess and also exhibiting a clear monotonic exposure-response gradient. There was also some evidence of an exposure-response gradient in men for death from all causes, primary liver cancer, cancer of the lymphatic/ haematopoietic system, Hodgkin's disease and ischemic heart disease; however, the gradients were weak. Mortality from cancer of the esophagus, colon, primary liver, non-Hodgkin's lymphoma and from bronchitis were elevated overall ( $\mathrm{HR} \geq 1.5$ ), but did not show consistent evidence of an exposure-response gradient. Although no deaths from asthma occurred among men unexposed to chemicals, there were nine deaths among the exposed. Among men, the relative risk was statistically significant in the third tertile of TCE exposure for death from all causes and ischemic heart disease and in the second and third tertiles for death from nonmalignant respiratory disease. The relative risk was elevated $(\mathrm{HR} \geq 1.5)$ in the third tertile of TCE exposure, and greater than the lower two tertiles, for death from cancer of the biliary passage/liver and primary liver, Hodgkin's disease and non-malignant respiratory disease. Among women, there were no statistically significant increased relative risks for overall exposure, although the numbers of deaths for each specific cause were small, limiting sensitivity. There was a statistically significant increased risk of death from diabetes in the lowest tertile of TCE exposure, and there was an apparent exposure-response gradient for death from cervical cancer, cerebrovascular disease, emphysema and suicide. Among women, the relative risk was elevated $(\mathrm{HR} \geq 1.5)$ in the highest tertile of TCE exposure, and greater than the lower two tertiles, for death from rectal cancer, cervical cancer, endocrine cancers, emphysema and suicide.

Tables 4 and 5 provide hazard ratios for various causes of death by categories of TCE exposure, for men and women, respectively. For low level exposures in men, there was an increase in relative risk of 0.30 or more for continuous compared to intermittent exposure for death from Hodgkin's disease and cancer of the buccal cavity/pharynx, central nervous system and the lymphatic/haematopoietic system, and from non-malignant respiratory disease, bronchitis and emphysema. The relative risk was statistically significant in the continuous TCE exposure category for death from all cancers and from non-malignant respiratory disease. The relative risk was elevated $(\mathrm{HR} \geq 1.5)$ in the continuous TCE exposure category and greater than in the intermittent TCE exposure category for death from colon cancer, kidney cancer, Hodgkin's disease, non-Hodgkin's lymphoma, non-malignant respiratory disease and bronchitis. For peak exposures in men, there was an increase in relative risk of 0.30 or more for frequent compared to infrequent exposure for death from stomach cancer, Hodgkin's disease, bronchitis and motor vehicle accidents. The relative risk was statistically significant in the frequent TCE exposure category for death from all causes and from non-malignant respiratory disease. The relative risk was elevated $(\mathrm{HR} \geq 1.5)$ in the frequent TCE exposure category and greater than in the infrequent TCE exposure category for death from colon cancer, Hodgkin's disease and bronchitis. For low level exposures in women, there was an increase in relative risk of 0.30 or more for continuous compared to intermittent exposure for death from lung and bone cancers, cerebrovascular diseases, bronchitis and emphysema. The relative risk was not statistically significant in the continuous TCE exposure category for any cause of death, although it was statistically significant for death from breast cancer, multiple myeloma and diabetes in the 
intermittent exposure category. The relative risk was elevated $(\mathrm{HR} \geq 1.5)$ in the continuous TCE exposure category, and greater than in the intermittent TCE exposure category, for death from bone cancer and bronchitis. For peak exposures in women there was an increase in relative risk of 0.30 or more for frequent compared to infrequent exposure for death from diabetes and cerebrovascular diseases. The relative risk was statistically significant in the frequent TCE exposure category for death from cerebrovascular disease. The relative risk was elevated $(\mathrm{HR} \geq 1.5)$ in the frequent TCE exposure category, and greater than in the infrequent TCE exposure category, for death from cancer of the pancreas, kidney and endocrine system and from cerebrovascular disease, bronchitis, emphysema and suicide.

Tables 6 through 9 provide hazard ratios for death from breast cancer, non-Hodgkin's lymphoma, multiple myeloma and non-malignant respiratory disease, respectively, for other chemicals used at the base. Hazard ratios were elevated for a number of exposures, but most associations were not statistically significant. For death from breast cancer (Table 6), there were statistically significant increased relative risks for subjects exposed to freon, isopropyl alcohol and solder flux. In addition, there was a $50 \%$ or greater relative excess observed for 1,1,1-trichloroethane, methylene chloride and methyl ethyl ketone (all p>0.05) with at least three deaths. For death from non-Hodgkin's lymphoma (Table 7) there were no statistically significant associations for men or women although a relative excess of $50 \%$ or more was observed for exposure to 1,1,1-trichloroethane, freon, isopropyl alcohol, JP4 gasoline, methylene chloride, O-dichlorobenzene, other alcohols, perchloroethylene and solder flux with at least three deaths among men, and freon, isopropyl alcohol, and solder flux with at least three deaths among women (all p>0.05). For death from multiple myeloma (Table 8), there were no statistically significant increased relative risks for men, although there was a 50\% or greater relative excess for male subjects exposed to freon, methylene chloride, O-

dichlorobenzene, other alcohols and perchloroethylene (all $\mathrm{p}>0.05$ ) with at least three deaths. For women, there were statistically significant increased relative risks for subjects exposed to 1,1,1-trichloroethane, methyl ethyl ketone, and toluene with at least three deaths. These statistically significant relative risks were large, ranging from 4.5 to 14.5 , but the numbers of deaths were small and confidence intervals were wide. In addition, a 50\% or greater relative excess for women was observed for exposure to any solvent, carbon tetrachloride, Stoddard Solvent and zinc chromate (all p $>0.05$ ) with at least three deaths. For death from non-malignant respiratory disease (Table 9), there was a statistically significant increased relative risk for men exposed to several chemicals: any solvent, carbon tetrachloride, freon, isopropyl alcohol, JP4 gasoline, methylene chloride, methyl ethyl ketone, O-dichlorobenzene, perchloroethylene, Stoddard solvent, toluene, and zinc chromate. These relative excesses ranged from approximately $30 \%$ to $80 \%$. There were no statistically significant excesses found for women and only one exposure was associated with a greater than $50 \%$ relative excess in womenother alcohols $(\mathrm{p}>0.05)$.

Finally, in analyses of all other chemicals and causes of death, most associations were not statistically significant, although we did find several that were (Table 10). Notably, all-cause mortality risk was significantly elevated for both men and women exposed to O-

dichlorobenzene and silica.

\section{Discussion}

We extended by 10 years the mortality follow up investigation of the Hill Air Force Base cohort previously reported by Blair et al. ${ }^{7}$ In that study, only two statistically significant excesses were reported for workers exposed to TCE compared to workers with no chemical exposure: death from all cancers (relative risk $=1.1$ ) and ischemic heart disease (relative risk $=1.1$ ). In this update, we did not find any statistically significant associations for TCE, although more than $70 \%$ of the hazard ratios associated with ever exposed to TCE were greater than 1.0. The 
results for the relative risk of death from all cancers and ischemic heart disease were only slightly lower than in 1990. Most other associations were similar or changed only modestly between the 1990 and 2000 follow ups. There was a 0.30 or greater change in relative risk between the 1990 and 2000 follow ups for only a few causes of death: a decrease in the relative risk of death from cancer of the buccal cavity/pharynx (relative risk $=1.4$ and 1.1, respectively), esophagus (relative risk $=5.6$ and 1.9, respectively), primary liver (relative risk $=1.7$ and 1.3 , respectively), breast (relative risk $=1.8$ and 1.2, respectively), kidney (relative risk $=1.6$ and 1.2 , respectively) and bladder (relative risk $=1.2$ and 0.8 , respectively), non-Hodgkin's lymphoma (relative risk $=2.0$ and 1.4 , respectively) and asthma (relative risk $=1.7$ and 1.2 , respectively), and an increase in the relative risk of death from cancer of the rectum (relative risk $=0.4$ and 0.7 , respectively) and bone (relative risk $=2.1$ and 3.7, respectively) and bronchitis (relative risk $=2.4$ and 3.6, respectively). All other associations involved less than a 0.30 change in relative risk between 1990 and 2000 .

In exposure-response analyses of TCE cumulative exposure, the monotonic exposure response gradients observed for ischemic heart disease and non-malignant respiratory disease in men in the 1990 follow up were also observed in the 2000 follow up, although the gradient was weaker for the latter in the most recent follow up. Of the gradients (defined as an increase in relative risk of 0.30 or more) we observed in 2000 for low level continuous compared to intermittent exposure, death from non-malignant respiratory disease and bronchitis had similarly strong gradients in 1990. (Results were not reported in the 1990 follow up for cancer of the buccal cavity/pharynx, central nervous and lymphatic/haematopoietic systems or Hodgkin's disease or emphysema). The gradient in the 1990 follow up for cancer of the stomach was no longer apparent in 2000 and the gradient in 1990 for non-Hodgkin's lymphoma was similar in 2000, although slightly less pronounced. In women, the gradient reported for the TCE cumulative exposure score for cerebrovascular disease in 1990 was also observed in the 2000 follow up, although the gradient was weaker in the latter follow up. In the exposure-response analyses of categories of TCE exposure in women, of the gradients we observed in 2000 for low level continuous compared to intermittent exposure (i.e., death from lung and bone cancers, cerebrovascular diseases, bronchitis and emphysema), only bronchitis was reported in the 1990 follow up and bronchitis had no deaths in any category in 1990. The gradient reported in the 1990 follow up for breast cancer was no longer apparent in the 2000 follow up. In general, for men and women, relative risks in most categories of the exposure response analyses were not statistically significant in either the 1990 or 2000 follow up, and since the number of deaths for particular causes often increased by only a few, there was not much opportunity for results to change substantially. Therefore, we observed no major changes in exposure-response gradients for TCE between the 1990 and 2000 follow up.

Overall, our results for TCE do not provide statistically significant associations with cancers that have been reported in other studies - kidney, liver/biliary tract, cervix and esophagus, and non-Hodgkin's lymphoma, multiple myeloma and Hodgkin's disease. ${ }^{5,6}$ However, all of these cancers do show non-statistically significant excesses in our study, some with point estimates greater than 1.5, and, therefore, our results are not inconsistent with the literature. Recently, Mandel and colleagues conducted a meta-analysis and literature review of the association between TCE and non-Hodgkin's lymphoma and found a high level of variability in study results, which complicated interpretation. ${ }^{21}$ Our relative risk point estimate of 1.4 for TCE and non-Hodgkin's lymphoma, although not statistically significant, is within the range of summary relative risk estimates reported by those authors. Scott and Chiu conducted a broader review of the TCE epidemiology, looking at several types of cancer. ${ }^{22}$ The authors examined recent cohort, case-control and community studies and concluded that there is a growing body of evidence supporting an association between TCE and cancers of the kidney, liver and lymphatic systems with relative risks ranging between 1.5 and 2.0. Our point estimates of 1.2, 1.3 and 1.4 for kidney cancer, liver cancer and non-Hodgkin's lymphoma, respectively, although not 
statistically significant, are generally consistent with their conclusions. The authors also reported the relative risks for other cancers from recent cohort studies including bladder, breast and esophagus and again our point estimates are generally comparable. Tables 4-7 and figures 1-4 of Scott and Chiu's paper suggest that relative risk estimates can vary substantially across studies and that relatively few associations reported in TCE cohort studies are statistically significant. A majority of these cohort studies have seemingly encountered similar methodological issues that we have - especially the statistical limitations of analyzing small numbers. The authors discuss some of the other key challenges in drawing strong causal conclusions about TCE and cancer risk in past studies including problems with using mortality as opposed to cancer incidence data (i.e., death certificate inaccuracies), exposure assessment difficulties (i.e., lack of actual exposure measurements necessitates the use of proxies such as assigning exposure scores based upon historical industrial hygiene surveys and/or interviews) and the fact that study subjects usually have multiple exposures. These challenges are clearly relevant to our study as well.

In analyses of other chemicals, the statistically significant relative risks in the 1990 follow up for death from breast cancer among women exposed to 1,1,1-trichloroethane, freon, isopropyl alcohol, methylene chloride and solder flux (relative risk = 3.3, 3.8, 3.7, 3.0 and 3.7, respectively) decreased slightly in the 2000 follow up, although freon, isopropyl alcohol and solder flux remained statistically significant (relative risk $=2.7,2.6$ and 2.8 , respectively). The statistically significant relative risks for death from non-Hodgkin's lymphoma in women exposed to isopropyl alcohol and solder flux in the 1990 follow up (relative risk $=5.8$ and 6.5, respectively) were attenuated and not statistically significant in the 2000 follow up (relative risk $=2.1$ and 2.6 , respectively). For death from multiple myeloma, the statistically significant relative risks in women exposed to 1,1,1-trichloethane and toluene in the 1990 follow up (relative risk $=13.2$ and 5.0, respectively) remained about the same and statistically significant in the 2000 follow up (relative risk $=14.5$ and 4.5 , respectively). In 2000, we found statistically significant elevated relative risks for exposure to methyl ethyl ketone and perchloroethylene that were not observed/reported in the 1990 follow up. No relative risks for death from multiple myeloma in males were statistically significant in either the 1990 or 2000 follow up. Overall, since the number of deaths for particular exposures often increased by only a few for these causes, there was not much opportunity for results to change substantially between the follow ups.

In a hypothesis generating exercise (Table 10) we found few statistically significant excesses, but both men and women exposed to O-dichlorobenzene and silica experienced a significantly elevated mortality from all causes. Silica is a known carcinogen ${ }^{3}$ and is associated with nonmalignant respiratory disease ${ }^{23}$ and renal disease, ${ }^{24}$ but there is inadequate information on the carcinogenicity and long-term health hazards of O-dichlorobenzene. ${ }^{25}$ Caution should be exercised in interpreting these results because confidence intervals for associations with a small number of exposed cases tended to be wide and relative risks for associations with a large number of exposed cases tended to be closer to unity. In addition, no adjustments were made for multiple comparisons.

One of the most consistent findings from our study was that of a moderate $30 \%$ to $80 \%$ relative excess of death for non-malignant respiratory disease in men for TCE and several other chemicals. We could not attribute this to specific causes such as emphysema or bronchitis, although for many chemicals we did observe elevated, but not statistically significant, relative risks for bronchitis (see Tables 1-5 for TCE; data not shown for other chemicals). Also noteworthy was that for TCE in men, the relative risk of death from asthma could not be computed because all nine deaths were exposed. There is some evidence in the literature of associations between occupational exposures and chronic respiratory diseases ${ }^{26-29} \mathrm{We}$ observed clear monotonic exposure-response gradients in men for TCE for this particular cause 
of death and this increases the likelihood of a true cause-effect relationship, although since workers had multiple chemical exposures we cannot single out TCE or any other chemical. Confounding from smoking and/or other lifestyle variables is a possible alternative explanation. We lacked information on tobacco use, but we do know there was a difference in the socioeconomic status (SES) of the exposed and unexposed workers in the cohort ${ }^{1}$ and SES has been linked to respiratory disease risk. ${ }^{30,31}$ Confounding of occupational associations from smoking, however, is rare because tobacco use is usually not related to exposure. ${ }^{32,33} \mathrm{In}$ addition, we observed no relationship between TCE exposure and lung cancer, which we should have seen if smoking confounded our evaluation of mortality risk for this chemical.

Our study had several strengths. First, the cohort was relatively large with a long follow up period. Second, the cohort design allowed for the ascertainment of the outcome after information on the exposure was obtained, thereby limiting the risk of reporting bias. Third, the exposure assessment conducted by the NCI was based on information regarding exposure and work processes provided by the Air Force for 14 solvents and seven other chemicals. Fourth, we used an internal comparison group, which minimizes concerns over biases such as the healthy worker effect (thought primarily to be a problem with non-malignant diseases like heart disease) when an external comparison is used.

Our study also had several limitations. First, despite the large sample size, there were relatively few cases for many causes of death from specific exposures and, therefore, statistical associations often were not robust. Second, exposures were not mutually exclusive which prevented us from evaluating the risk of death from individual chemicals while controlling for exposure to other chemicals used at the base. This problem however is not unique to this study because multiple exposures, whether occupational or lifestyle, are the normal human condition. Third, exposure misclassification was a possibility in our study because exposure records specific to the study subjects did not exist; monitoring and chemical use records were insufficient for all jobs and locations. Exposure was, therefore, estimated based on position descriptions and other historical documents from the base. Although this approach is not unusual in cohort studies, oftentimes the link between exposure and subjects is stronger than it was in this study. This could affect both the main analyses and the exposure-response analyses for TCE. We believe that the misclassification was random, and our results are biased towards the null. Fourth, we relied upon mortality data for estimating disease incidence. As mentioned earlier, mortality data can be misleading because of inaccuracies in patient death records - such inaccuracies could result in the attenuation of true associations. Fifth, the study population was predominantly white (87\%) and male (74\%). Results for women tended to differ from those for men, but due to smaller numbers for women it was difficult to fully evaluate gender effects. In addition, we were unable to evaluate risks among non-white cohort members because of small numbers. Sixth, Spirtas et al. ${ }^{1}$ reported that the proportion of workers at the base with no chemical exposure who were salaried was $61 \%$ compared with less than $1 \%$ of exposed workers, indicating that the groups had dissimilar SES. SES is associated with some of the diseases we studied including certain cancers, cardiovascular disease and diabetes. ${ }^{34}$ Seventh, multiple comparisons were made and some associations would be expected due to chance alone. Eighth, none of the associations in the main analyses for TCE in the 1990 or 2000 follow up were statistically significant and the changes may represent chance variation. Alternatively, any decreases from 1990 may represent a natural decrease in risk as the time since first exposure has increased. Finally, other than age, gender and race, data on lifestyle and other nonoccupational risk factors such as disease history and SES, which might confound the relationship between exposure and disease, or which might be effect modifiers, were not available for the cohort. 


\section{Conclusion}

Overall, patterns of mortality have not changed substantially since the last follow up of the Hill Air Force Base cohort in 1990. We observed no increased risk of death from all causes or all cancers in 2000. An increased risk of death from a number of individual causes was observed for some of the chemicals used at the base, and statistically significant associations for certain exposures were evident in the 2000 follow up. For TCE, although we observed many hazard ratios greater than unity, we observed only a few monotonic exposure-response gradients, most of which were relatively weak. For all chemicals studied there were inconsistencies in associations by gender, and relative risks tended to be small and/or confidence intervals wide. Small numbers for many exposure-disease comparisons limited interpretation. For these reasons, there is not strong evidence that exposed workers at the base have experienced a major excess in mortality. There is, however, suggestive evidence for a number of specific causes of death, and many of the elevated risks observed are generally consistent with previous studies. Therefore, further research is warranted.

\section{Acknowledgement}

This research was supported in part by the Intramural Research Program of the National Institutes of Health (National Cancer Institute, Division of Cancer Epidemiology and Genetics) and by an unrestricted educational grant from Merck \& Co., Inc.

\section{References}

1. Spirtas R, Stewart PA, Lee JS, et al. Retrospective cohort mortality study of workers at an aircraft maintenance facility. I Epidemiological results. Br J Ind Med 1991;48:515-530. [PubMed: 1878308]

2. Stewart PA, Lee JS, Marano DE, Spirtas R, Forbes CD, Blair A. Retrospective cohort mortality study of workers at an aircraft maintenance facility. II Exposures and their assessment. Br J Ind Med 1991;48:531-537. [PubMed: 1878309]

3. Siemiatycki J, Richardson L, Straif K, et al. Listing occupational carcinogens. Environ Health Perspect 2004;112:1447-1459. [PubMed: 15531427]

4. Frangos SA, Peters JM. Chlorinated hydrocarbons solvents: substituting our way toward human carcinogenicity. Am J Ind Med 1993;24:355-364. [PubMed: 8250056]

5. Weiss NS. Cancer in relation to occupational exposure to trichloroethylene. Occup Environ Med 1996;53:1-5. [PubMed: 8563851]

6. Wartenberg D, Reyner D, Scott CS. Trichloroethylene and cancer: epidemiologic evidence. Environ Health Perspect 2000;108(Suppl 2):161-176. [PubMed: 10807550]

7. Blair A, Hartge P, Stewart PA, McAdams M, Lubin J. Mortality and cancer incidence of aircraft maintenance workers exposed to trichloroethylene and other organic solvents and chemicals: extended follow up. Occup Environ Med 1998;55:161-171. [PubMed: 9624267]

8. Anttila A, Pukkala E, Sallmen M, Hernberg S, Hemminki K. Cancer incidence among Finnish workers exposed to halogenated hydrocarbons. J Occup Environ Med 1995;37:797-806. [PubMed: 7552463]

9. Ritz B. Cancer mortality among workers exposed to chemicals during uranium processing. J Occup Environ Med 1999;41:556-566. [PubMed: 10412097]

10. Raaschou-Nielsen O, Hansen J, McLaughlin JK, et al. Cancer risk among workers at Danish companies using trichloroethylene: a cohort study. Am J Epidemiol 2003;158:1182-1192. [PubMed: 14652303]

11. Henschler D, Vamvakas S, Lammert M, et al. Increased incidence of renal cell tumors in a cohort of cardboard workers exposed to trichloroethylene. Arch Toxicol 1995;69:291-299. [PubMed: 7654132]

12. Zhao Y, Krishnadasan A, Kennedy N, Morgenstern H, Ritz B. Estimated effects of solvents and mineral oils on cancer incidence and mortality in a cohort of aerospace workers. Am J Ind Med 2005;48:249-258. [PubMed: 16167347] 
13. Hansen J, Raaschou-Nielsen O, Christensen JM, et al. Cancer incidence among Danish workers exposed to trichloroethylene. J Occup Environ Med 2001;43:133-139. [PubMed: 11227631]

14. Axelson O, Selden A, Andersson K, Hogstedt C. Updated and expanded Swedish cohort study on trichloroethylene and cancer risk. J Occup Med 1994;36:556-562. [PubMed: 8027881]

15. Morgan RW, Kelsh MA, Zhao K, Heringer S. Mortality of aerospace workers exposed to trichloroethylene. Epidemiol 1998;9:424-431.

16. Boice JD, Marano DE, Fryzek JP, Sadler CJ, McLaughlin JK. Mortality among aircraft manufacturing workers. Occup Environ Med 1999;56:581-597. [PubMed: 10615290]

17. Chang YM, Tai CF, Yang SC, et al. A cohort mortality study of workers exposed to chlorinated organic solvents in Taiwan. Ann Epidemiol 2003;13:652-660. [PubMed: 14732305]

18. National Death Index (NDI). Centers for Disease Control and Prevention. National Center for Health Statistics; Hyattsville, MD: US Department of Health and Human Services.

19. Breslow NE, Lubin JH, Marek P, Langholz B. Multiplicative models and cohort analysis. J Am Stat Assoc 1983;78:1-12.

20. Checkoway, H.; Pearce, NE.; Crawford-Brown, DJ. Research Methods in Occupational Epidemiology. Vol. 90. Oxford University Press; New York: p. 1989

21. Mandel JH, Kelsh MA, Mink PJ, et al. Occupational trichloroethylene exposure and non-Hodgkin's lymphoma: a meta-analysis and review. Occup Environ Med 2006;63:597-607. [PubMed: 16644896]

22. Scott CS, Chiu WA. Trichloroethylene cancer epidemiology: a consideration of select issues. Environ Health Perspect 2006;114:1471-1478. [PubMed: 16966107]

23. McDonald AD, McDonald JC, Rando RJ, Hughes JM, Weill H. Cohort mortality study of North American industrial sand workers. I. Mortality from lung cancer, silicosis, and other causes. Ann Occup Hyg 2001;45:193-199. [PubMed: 11295142]

24. Calvert GM, Steenland K, Palu S. End-stage renal disease among silica-exposed gold-miners. A new method for assessing incidence among epidemiologic cohorts. JAMA 1997;277:1219-1223. [PubMed: 9103346]

25. IARC. IARC monographs on the evaluation of carcinogenic risk of chemicals to man. World Health Organization, International Agency for Research on Cancer; Lyon, France: 1987.

26. Schenker MB, Jacobs JA. Respiratory effects of organic solvent exposure. Tuber Lung Dis 1996;77:418. [PubMed: 8733408]

27. Viegi G, Di Pede C. Chronic obstructive lung diseases and occupational exposure. Curr Opin Allergy Clin Immunol 2002;2:115-121. [PubMed: 11964759]

28. Trupin L, Earnest G, San Pedro M, et al. The occupational burden of chronic obstructive pulmonary disease. Eur Respir J 2003;22:462-469. [PubMed: 14516136]

29. Anto JM, Vermeire P, Vestbo J, Sunyer J. Epidemiology of chronic obstructive pulmonary disease. Eur Respir J 2001;17:982-994. [PubMed: 11488336]

30. Trinder PM, Croft PR, Lewis M. Social class, smoking and the severity of respiratory symptoms in the general population. J Epidemiol Community Health 2000;54:340-343. [PubMed: 10814653]

31. Montnemery P, Bengtsson P, Elliot A, Lindholm LH, Nyberg P, Lofdahl CG. Prevalence of obstructive lung diseases and respiratory symptoms in relation to living environment and socioeconomic group. Respir Med 2001;95:744-752. [PubMed: 11575896]

32. Axelson O, Steenland K. Indirect methods of assessing the effects of tobacco use in occupational studies. Am J Ind Med 1988;13:105-118. [PubMed: 3344750]

33. Blair A, Hoar S, Walrath J. Comparison of crude and smoking-adjusted standardized mortality ratios. J Occup Med 1985;27:881-884. [PubMed: 4087053]

34. Adler NE, Ostrove JM. Socio-economic status and health: what we know and what we don't. Ann NY Acad Sci 1999;896:3-15. [PubMed: 10681884] 
Table 1

Comparison of Poisson model rate ratios (95\% confidence intervals) and numbers of cases, and Cox model hazard ratios ( $95 \%$ confidence intervals) for selected causes of death among workers exposed to trichloroethylene, 1990 follow up, and Cox model hazard ratios (95\% confidence intervals) and numbers of cases, 2000 follow up

\begin{tabular}{|c|c|c|c|c|}
\hline \multirow[t]{2}{*}{$\begin{array}{l}\text { Cause of death (ICDA-8) (ICD-9) } \\
\text { (ICD-10) }\end{array}$} & \multicolumn{3}{|c|}{$\begin{array}{l}\text { 1990 Follow up } \\
\text { (ICDA-8) }\end{array}$} & \multirow{2}{*}{\begin{tabular}{|l} 
2000 Follow up \\
(ICDA-8, ICD-9 \\
and ICD-10) \\
Cox Model \\
Hazard Ratio \\
$(95 \%$ CI), \\
No. Exp Cases
\end{tabular}} \\
\hline & \begin{tabular}{|l} 
Poisson Model \\
Rate Ratio \\
(95\% CI), \\
No. Exp \\
Cases \\
\end{tabular} & $\begin{array}{l}\text { Cox } \\
\text { Model 1 }{ }^{\dagger} \\
\text { Hazard Ratio } \\
(95 \% \text { CI })\end{array}$ & \begin{tabular}{|l|} 
Cox \\
Model 2 \\
Hazard Ratio \\
$(95 \%$ CI $)$
\end{tabular} & \\
\hline $\begin{array}{l}\text { All causes }(000-999)(000-999) \\
\text { (A00-Y89.9) }\end{array}$ & $\begin{array}{l}1.0(1.0-1.1) \\
2813\end{array}$ & $1.0(0.9-1.0)$ & $1.0(0.9-1.1)$ & $\begin{array}{l}1.04(0.98-1.09) \\
4320\end{array}$ \\
\hline $\begin{array}{l}\text { All cancers }(140-209)(140-209) \\
\text { (C00-C97) }\end{array}$ & $\begin{array}{l}1.1(1.0-1.3) \\
528\end{array}$ & $1.1(0.9-1.2)$ & $1.0(0.9-1.2)$ & $\begin{array}{l}1.03(0.91-1.17) \\
854\end{array}$ \\
\hline $\begin{array}{l}\text { Buccal cavity/pharynx (140-149) } \\
(140-149)(\text { C00-C14) }\end{array}$ & $\begin{array}{l}1.4(0.4-5.2) \\
9\end{array}$ & $1.4(0.4-5.6)$ & $1.4(0.4-5.6)$ & $\begin{array}{l}1.12(0.40-3.14) \\
13\end{array}$ \\
\hline $\begin{array}{l}\text { Digestive organs (150-159) (150- } \\
\text { 159) (C15-C26) }\end{array}$ & $\begin{array}{l}1.2(0.9-1.7) \\
142\end{array}$ & $1.1(0.8-1.5)$ & $1.1(0.8-1.5)$ & $\begin{array}{l}1.10(0.86-1.41) \\
232\end{array}$ \\
\hline Esophagus (150) (150) (C15) & $\begin{array}{l}5.6(0.7-44.5) \\
10\end{array}$ & $5.0(0.6-41.4)$ & $5.0(0.6-41.4)$ & $\begin{array}{l}1.88(0.61-5.79) \\
17\end{array}$ \\
\hline Stomach (151) (151) (C16) & $\begin{array}{l}0.9(0.4-1.9) \\
23\end{array}$ & $0.7(0.3-1.4)$ & $0.7(0.3-1.3)$ & $\begin{array}{l}0.67(0.38-1.20) \\
32\end{array}$ \\
\hline Colon (153) (153) (C18) & $\begin{array}{l}1.4(0.8-2.4) \\
54\end{array}$ & $1.4(0.8-2.4)$ & $1.3(0.8-2.1)$ & $\begin{array}{l}1.35(0.90-2.02) \\
92\end{array}$ \\
\hline Rectum (154) (154) (C19, C20) & $\begin{array}{l}0.4(0.1-1.5) \\
5\end{array}$ & $0.4(0.1-1.5)$ & $0.4(0.1-1.5)$ & $\begin{array}{l}0.65(0.22-1.93) \\
9\end{array}$ \\
\hline $\begin{array}{l}\text { Biliary passage/liver }(155,156) \\
(155,156)(\mathrm{C} 22-\mathrm{C} 24)\end{array}$ & $\begin{array}{l}1.3(0.5-3.4) \\
15\end{array}$ & $1.2(0.5-3.4)$ & $1.2(0.5-3.4)$ & $\begin{array}{l}1.12(0.57-2.19) \\
31\end{array}$ \\
\hline $\begin{array}{l}\text { Primary liver (155.0) (155.0) } \\
\text { (C220) }\end{array}$ & $\begin{array}{l}1.7(0.2-16.2) \\
4\end{array}$ & $1.3(0.1-12.0)$ & $1.3(0.1-12.0)$ & $\begin{array}{l}1.25(0.31-4.97) \\
8\end{array}$ \\
\hline Pancreas (157) (157) (C25) & $\begin{array}{l}1.2(0.6-2.3) \\
33\end{array}$ & $1.2(0.6-2.3)$ & $1.2(0.6-2.3)$ & $\begin{array}{l}1.06(0.61-1.84) \\
46\end{array}$ \\
\hline Lung (162) (162) (C33, C34) & $\begin{array}{l}0.9(0.6-1.3) \\
109\end{array}$ & $0.8(0.6-1.2)$ & $0.8(0.6-1.1)$ & $\begin{array}{l}0.83(0.63-1.08) \\
166 \\
\end{array}$ \\
\hline Breast (174) (174) (C50) & $\begin{array}{l}1.8(0.9-3.3) \\
20\end{array}$ & $1.7(0.9-3.1)$ & $1.8(1.0-3.3)$ & $\begin{array}{l}1.23(0.73-2.06) \\
26\end{array}$ \\
\hline Cervix (180) (180) (C53) & $1.8(0.5-6.5)$ & $1.4(0.4-4.5)$ & $1.4(0.4-4.5)$ & $\begin{array}{l}1.67(0.54-5.22) \\
6\end{array}$ \\
\hline Prostate (185) (185) (C61) & $\begin{array}{l}1.1(0.6-1.8) \\
54\end{array}$ & $0.9(0.6-1.6)$ & $1.0(0.6-1.6)$ & $\begin{array}{l}1.20(0.82-1.76) \\
116 \\
\end{array}$ \\
\hline Kidney (189.0) (189.0) (C64) & $\begin{array}{l}1.6(0.5-5.1) \\
15\end{array}$ & $2.3(0.6-8.4)$ & $2.3(0.6-8.4)$ & $\begin{array}{l}1.18(0.47-2.94) \\
18\end{array}$ \\
\hline Bladder (188) (188) (C67) & $\begin{array}{l}1.2(0.5-2.9) \\
17 \\
\end{array}$ & $1.1(0.4-2.7)$ & $1.1(0.5-2.8)$ & $\begin{array}{l}0.80(0.41-1.58) \\
25\end{array}$ \\
\hline $\begin{array}{l}\text { Melanoma of skin }(172.0-172.4 \text {, } \\
172.6-172.9)(172)(\mathrm{C} 43)\end{array}$ & $\begin{array}{l}1.0(0.3-3.1) \\
9\end{array}$ & $0.9(0.3-3.0)$ & $0.9(0.3-3.0)$ & $\begin{array}{l}0.84(0.32-2.20) \\
13\end{array}$ \\
\hline $\begin{array}{l}\text { Central Nervous System (191, } \\
\text { 192) }(191,192)(\text { C71, C72) } \\
\end{array}$ & $\begin{array}{l}0.8(0.2-2.2) \\
11\end{array}$ & $0.9(0.3-2.7)$ & $0.9(0.3-2.7)$ & $\begin{array}{l}1.02(0.39-2.67) \\
17\end{array}$ \\
\hline $\begin{array}{l}\text { Endocrine }(193,194)(193,194) \\
\text { (C73-C75) }\end{array}$ & $\begin{array}{l}0.7(0.1-5.4) \\
2\end{array}$ & $0.7(0.1-5.2)$ & $0.8(0.1-5.4)$ & $\begin{array}{l}0.83(0.13-5.38) \\
3\end{array}$ \\
\hline Bone (170) (170) $(\mathrm{C} 40, \mathrm{C} 41)$ & $2.1(0.2-18.8)$ & $2.3(0.2-22.1)$ & $2.3(0.2-22.1)$ & $\begin{array}{l}3.68(0.40-33.63) \\
6\end{array}$ \\
\hline Lymphatic or haematopoietic (200-209) (200-208) (C81-C96) & $\begin{array}{l}1.1(0.7-1.8) \\
66\end{array}$ & $1.1(0.7-1.8)$ & $1.1(0.7-1.8)$ & $\begin{array}{l}1.06(0.75-1.51) \\
106\end{array}$ \\
\hline $\begin{array}{l}\text { Hodgkin's Disease (201) (201) } \\
\text { (C81) }\end{array}$ & $1.4(0.2-12.0)$ & $1.5(0.2-12.6)$ & $1.5(0.2-12.6)$ & $1.47(0.17-12.58)$ \\
\hline $\begin{array}{l}\text { Non-Hodgkin's Lymphoma }(200,202)(200, \\
\text { 202)(C82-C85) }\end{array}$ & $\begin{array}{l}2.0(0.9-4.6) \\
28 \\
\end{array}$ & $2.0(0.9-4.5)$ & $2.0(0.9-4.5)$ & $\begin{array}{l}1.36(0.77-2.39) \\
46\end{array}$ \\
\hline $\begin{array}{l}\text { Multiple myeloma (203) (203) } \\
\text { (C90) }\end{array}$ & $\begin{array}{l}1.3(0.5-3.4) \\
14\end{array}$ & $1.2(0.4-3.1)$ & $1.2(0.4-3.1)$ & $\begin{array}{l}1.35(0.62-2.93) \\
25\end{array}$ \\
\hline $\begin{array}{l}\text { Leukemia (204-207) (204-208) } \\
\text { (C91-C95) }\end{array}$ & $\begin{array}{l}0.6(0.3-1.2) \\
16\end{array}$ & $0.6(0.3-1.3)$ & $0.7(0.3-1.4)$ & $\begin{array}{l}0.64(0.35-1.18) \\
27\end{array}$ \\
\hline $\begin{array}{l}\text { Ischemic Heart Disease (410-414) } \\
(410-414)(\mathrm{I} 20-\mathrm{I} 25)\end{array}$ & $\begin{array}{l}1.1(1.0-1.3) \\
948\end{array}$ & $1.1(0.9-1.2)$ & $1.1(1.0-1.2)$ & $\begin{array}{l}1.09(0.99-1.21) \\
1282 \\
\end{array}$ \\
\hline Diabetes (250) (250) (E10-E14) & $\begin{array}{l}1.3(0.8-2.2) \\
61\end{array}$ & $1.3(0.8-2.1)$ & $1.3(0.8-2.0)$ & $\begin{array}{l}1.25(0.90-1.74) \\
124\end{array}$ \\
\hline $\begin{array}{l}\text { Cerebrovascular Disease (430-438) } \\
(430-438)(160-\mathrm{I} 69)\end{array}$ & $\begin{array}{l}1.0(0.8-1.3) \\
161\end{array}$ & $0.8(0.6-1.1)$ & $0.8(0.7-1.1)$ & $\begin{array}{l}1.00(0.82-1.22) \\
288\end{array}$ \\
\hline $\begin{array}{l}\text { Non-Malignant Respiratory Disease } \\
(460-519)(460-519)(\mathrm{J} 00-\mathrm{J} 98)\end{array}$ & $\begin{array}{l}1.2(0.9-1.5) \\
234\end{array}$ & $1.1(0.8-1.4)$ & $1.1(0.9-1.4)$ & $\begin{array}{l}1.15(0.96-1.38) \\
407\end{array}$ \\
\hline
\end{tabular}




\begin{tabular}{|c|c|c|c|c|}
\hline \multirow[t]{2}{*}{ 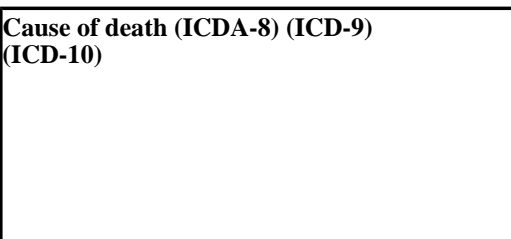 } & \multicolumn{3}{|c|}{$\begin{array}{l}1990 \text { Follow up } \\
\text { (ICDA-8) }\end{array}$} & \multirow{2}{*}{\begin{tabular}{|l|}
2000 Follow up \\
ICDA-8, ICD-9 \\
and ICD-10) \\
Cox Model \\
Hazard Ratio \\
$(95 \%$ CI), \\
No. Exp Cases \\
\end{tabular}} \\
\hline & \begin{tabular}{|l} 
Poisson Model \\
Rate Ratio \\
$(95 \%$ CI), \\
No. Exp \\
Cases \\
\end{tabular} & \begin{tabular}{|l|} 
Cox \\
Model 1 ${ }^{\dagger}$ \\
Hazard Ratio \\
$(95 \%$ CI $)$
\end{tabular} & \begin{tabular}{|l|} 
Cox \\
Model $2^{\S}$ \\
Hazard Ratio \\
$(95 \%$ CI $)$
\end{tabular} & \\
\hline $\begin{array}{l}\text { Bronchitis }(490,491)(490,491) \\
(\mathrm{J} 40, \mathrm{~J} 41)\end{array}$ & $\begin{array}{l}2.4(0.5-11.3) \\
10\end{array}$ & $2.0(0.4-9.6)$ & $2.0(0.4-9.6)$ & $\begin{array}{l}3.63(0.80-16.48) \\
15\end{array}$ \\
\hline Emphysema (492) (492) (J34) & $\begin{array}{l}0.9(0.5-1.6) \\
44\end{array}$ & $0.7(0.4-1.2)$ & $0.7(0.4-1.2)$ & $\begin{array}{l}0.90(0.56-1.44) \\
59\end{array}$ \\
\hline Asthma (493) (493) (J45) & $\begin{array}{l}1.7(0.5-5.5) \\
11\end{array}$ & $1.9(0.6-6.4)$ & $1.9(0.6-6.4)$ & $\begin{array}{l}1.16(0.42-3.19) \\
11\end{array}$ \\
\hline $\begin{array}{l}\text { Cirrhosis }^{ \pm}(571.8,571.9)(571.5 \\
\text { 571.6) (K74.3-K74.6) }\end{array}$ & $\begin{array}{l}1.1(0.6-1.9) \\
44\end{array}$ & $1.0(0.5-2.2)$ & $1.0(0.5-2.1)$ & $\begin{array}{l}1.04(0.56-1.93) \\
37\end{array}$ \\
\hline $\begin{array}{l}\text { Motor Vehicle Accidents } \\
\text { (E810-E823) (E810-E825) (V20- } \\
\text { V69) }\end{array}$ & $\begin{array}{l}1.1(0.6-1.8) \\
52\end{array}$ & $1.1(0.6-1.9)$ & $1.1(0.7-1.8)$ & $\begin{array}{l}0.96(0.61-1.51) \\
66\end{array}$ \\
\hline Suicide (E950-E959) (E950-E959) (X60-X84) & $\begin{array}{l}0.8(0.5-1.3) \\
53\end{array}$ & $0.8(0.5-1.4)$ & $0.8(0.5-1.4)$ & $\begin{array}{l}1.04(0.65-1.67) \\
68\end{array}$ \\
\hline
\end{tabular}

$\mathrm{CI}=$ confidence interval; $\mathrm{ICD}=$ International Classification of Diseases

Referent group for all models: workers with no chemical exposure $(n=3,819)$

Poisson model: covariates = date of birth, calendar year of death and gender; from Blair et al. ${ }^{7}$

${ }^{\dagger}$ Cox regression model 1: time variable = age; covariate $=$ gender, using the same population as Blair et al. ${ }^{7}$

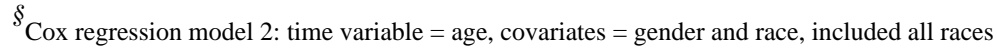

${ }^{ \pm}$Table 1 shows more cirrhosis deaths in 1990 than 2000 because the 2000 follow up excludes cirrhosis from alcohol 


\section{Table 2}

Hazard ratios (95\% confidence intervals) and numbers of cases for selected causes of death among male workers, by tertile of trichloroethylene cumulative exposure score

\begin{tabular}{|c|c|c|c|c|}
\hline Cause of death ${ }^{*}$ & All & 0-5 Unit Years & 5-25 Unit Years & $>25$ Unit Years \\
\hline All causes & $\begin{array}{l}1.04(0.98-1.11) \\
3628\end{array}$ & $\begin{array}{l}1.00(0.92-1.08) \\
1419\end{array}$ & $\begin{array}{l}1.05(0.97-1.15) \\
922\end{array}$ & $\begin{array}{l}1.09(1.01-1.18) \\
1287\end{array}$ \\
\hline All cancer & $\begin{array}{l}1.12(0.96-1.30) \\
729\end{array}$ & $\begin{array}{l}1.11(0.93-1.33) \\
297\end{array}$ & $\begin{array}{l}1.11(0.91-1.35) \\
183\end{array}$ & $\begin{array}{l}1.13(0.94-1.36) \\
249\end{array}$ \\
\hline $\begin{array}{l}\text { Buccal } \\
\text { cavity/pharynx }\end{array}$ & $\begin{array}{l}1.23(0.34-4.43) \\
11\end{array}$ & $1.36(0.32-5.71)$ & $\begin{array}{l}0.89(0.15-5.32) \\
2\end{array}$ & $1.33(0.30-5.97)$ \\
\hline Digestive organs & $\begin{array}{l}1.11(0.83-1.48) \\
200\end{array}$ & $\begin{array}{l}1.08(0.77-1.51) \\
80\end{array}$ & $\begin{array}{l}1.05(0.72-1.53) \\
48\end{array}$ & $\begin{array}{l}1.18(0.84-1.66) \\
72\end{array}$ \\
\hline Esophagus & $\begin{array}{l}1.66(0.48-5.74) \\
15\end{array}$ & $1.84(0.48-7.14)$ & $\begin{array}{l}1.33(0.27-6.59) \\
3\end{array}$ & $1.67(0.40-7.00)$ \\
\hline Stomach & $\begin{array}{l}0.68(0.36-1.29) \\
29\end{array}$ & $\begin{array}{l}0.58(0.26-1.31) \\
10\end{array}$ & $\begin{array}{l}0.73(0.30-1.74) \\
8\end{array}$ & $\begin{array}{l}0.76(0.34-1.67) \\
11\end{array}$ \\
\hline Colon & $\begin{array}{l}1.51(0.89-2.55) \\
76\end{array}$ & $\begin{array}{l}1.46(0.80-2.65) \\
30\end{array}$ & $\begin{array}{l}1.57(0.82-3.01) \\
20\end{array}$ & $\begin{array}{l}1.52(0.82-2.80) \\
26\end{array}$ \\
\hline Rectum & $\begin{array}{l}0.64(0.19-2.12) \\
8\end{array}$ & $0.76(0.19-3.05)$ & - & $0.96(0.24-3.85)$ \\
\hline $\begin{array}{l}\text { Biliary } \\
\text { passage/liver }\end{array}$ & $\begin{array}{l}1.36(0.59-3.11) \\
28\end{array}$ & $\begin{array}{l}1.17(0.45-3.09) \\
10\end{array}$ & $\begin{array}{l}1.16(0.39-3.46) \\
6\end{array}$ & $\begin{array}{l}1.72(0.68-4.38) \\
12\end{array}$ \\
\hline Primary liver & $\begin{array}{l}2.72(0.34-21.88) \\
8\end{array}$ & $\begin{array}{l}3.28(0.37-29.45) \\
4\end{array}$ & 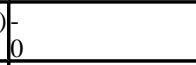 & $\begin{array}{l}4.05(0.45-36.41) \\
4\end{array}$ \\
\hline Pancreas & $\begin{array}{l}0.91(0.49-1.68) \\
39\end{array}$ & $\begin{array}{l}0.97(0.48-1.97) \\
17\end{array}$ & $\begin{array}{l}0.74(0.31-1.76) \\
8\end{array}$ & $\begin{array}{l}0.97(0.46-2.04) \\
14\end{array}$ \\
\hline Lung & $\begin{array}{l}0.91(0.67-1.24) \\
155\end{array}$ & $\begin{array}{l}0.96(0.67-1.37) \\
66\end{array}$ & $\begin{array}{l}0.71(0.46-1.11) \\
31\end{array}$ & $\begin{array}{l}1.00(0.69-1.45) \\
58\end{array}$ \\
\hline \multicolumn{5}{|l|}{ Breast } \\
\hline \multicolumn{5}{|l|}{ Cervix } \\
\hline Prostate & $\begin{array}{l}1.20(0.82-1.76) \\
116\end{array}$ & $\begin{array}{l}1.03(0.65-1.62) \\
41\end{array}$ & $\begin{array}{l}1.33(0.82-2.15) \\
32\end{array}$ & $\begin{array}{l}1.31(0.84-2.06) \\
43\end{array}$ \\
\hline Kidney & $\begin{array}{l}1.24(0.41-3.71) \\
16\end{array}$ & $\begin{array}{l}1.87(0.59-5.97) \\
10\end{array}$ & $\begin{array}{l}0.31(0.03-2.75) \\
1\end{array}$ & $1.16(0.31-4.32)$ \\
\hline Bladder & $\begin{array}{l}1.05(0.47-2.35) \\
24\end{array}$ & $\begin{array}{l}0.96(0.37-2.51) \\
9\end{array}$ & $\begin{array}{l}1.77(0.70-4.52) \\
10\end{array}$ & $\frac{0.65(0.21-1.98)}{5}$ \\
\hline Melanoma of skin & $\begin{array}{l}0.72(0.25-2.09) \\
11\end{array}$ & $\begin{array}{l}0.64(0.17-2.37) \\
4\end{array}$ & $\begin{array}{l}1.05(0.28-3.92) \\
4\end{array}$ & $\begin{array}{l}0.59(0.14-2.46) \\
3\end{array}$ \\
\hline $\begin{array}{l}\text { Central Nervous } \\
\text { System }\end{array}$ & $\begin{array}{l}1.26(0.43-3.75) \\
17\end{array}$ & $\begin{array}{l}1.46(0.44-4.86) \\
8\end{array}$ & $\begin{array}{l}1.74(0.49-6.16) \\
6\end{array}$ & $\begin{array}{l}0.66(0.15-2.95) \\
3\end{array}$ \\
\hline Endocrine & $\begin{array}{l}0.65(0.06-7.27) \\
2\end{array}$ & $\begin{array}{l}1.98(0.18-22.44) \\
2\end{array}$ & 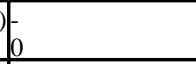 & 0 \\
\hline Bone & 0 unexp, $5 \exp$ & 0 unexp, $2 \exp$ & 0 unexp, 1 exp & 0 unexp, $2 \exp$ \\
\hline $\begin{array}{l}\text { Lymphatic or } \\
\text { haemat. }\end{array}$ & $\begin{array}{l}1.12(0.72-1.73) \\
88\end{array}$ & $\begin{array}{l}1.04(0.63-1.74) \\
34\end{array}$ & $\begin{array}{l}1.06(0.59-1.88) \\
21\end{array}$ & $\begin{array}{l}1.25(0.75-2.09) \\
33\end{array}$ \\
\hline Hodgkin's Disease & $1.47(0.17-12.58)$ & 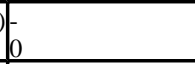 & $2.27(0.21-25.01)$ & $\begin{array}{l}2.59(0.27-24.94) \\
3\end{array}$ \\
\hline Non-Hodgkin's Lymph. & $\begin{array}{l}1.56(0.72-3.35) \\
37\end{array}$ & $\begin{array}{l}1.83(0.79-4.21) \\
18\end{array}$ & $1.17(0.42-3.24)$ & $\begin{array}{l}1.50(0.61-3.69) \\
12\end{array}$ \\
\hline Multiple myeloma & $\begin{array}{l}1.08(0.43-2.71) \\
19\end{array}$ & $\begin{array}{l}0.69(0.21-2.27) \\
5\end{array}$ & $\begin{array}{l}1.58(0.53-4.71) \\
7\end{array}$ & $1.19(0.40-3.54)$ \\
\hline Leukemia & $\begin{array}{l}0.77(0.37-1.62) \\
24\end{array}$ & $\begin{array}{l}0.86(0.36-2.02) \\
11\end{array}$ & $\begin{array}{l}0.51(0.16-1.63) \\
4\end{array}$ & $\begin{array}{l}0.87(0.35-2.14) \\
9\end{array}$ \\
\hline $\begin{array}{l}\text { Ischemic Heart } \\
\text { Disease }\end{array}$ & $\begin{array}{l}1.07(0.95-1.21) \\
1118\end{array}$ & $\begin{array}{l}0.98(0.85-1.13) \\
419\end{array}$ & $\begin{array}{l}1.11(0.95-1.30) \\
292\end{array}$ & $\begin{array}{l}1.15(1.00-1.33) \\
407\end{array}$ \\
\hline Diabetes & $\begin{array}{l}1.09(0.72-1.64) \\
93\end{array}$ & $\begin{array}{l}1.13(0.70-1.82) \\
39\end{array}$ & $\begin{array}{l}1.17(0.68-1.99) \\
25\end{array}$ & $\begin{array}{l}0.98(0.59-1.64) \\
29\end{array}$ \\
\hline $\begin{array}{l}\text { Cerebrovascular } \\
\text { Dis. } \\
\end{array}$ & $\begin{array}{l}0.92(0.71-1.18) \\
217\end{array}$ & $\begin{array}{l}0.85(0.63-1.16) \\
83\end{array}$ & $\begin{array}{l}0.68(0.47-0.99) \\
40\end{array}$ & $\begin{array}{l}1.17(0.87-1.56) \\
94\end{array}$ \\
\hline $\begin{array}{l}\text { Non-Mal. Resp. } \\
\text { Dis. }\end{array}$ & $\begin{array}{l}1.30(1.04-1.63) \\
354\end{array}$ & $\begin{array}{l}1.08(0.83-1.42) \\
122\end{array}$ & $\begin{array}{l}1.38(1.03-1.83) \\
93\end{array}$ & $\begin{array}{l}1.51(1.16-1.96) \\
139\end{array}$ \\
\hline Bronchitis & $\begin{array}{l}4.39(0.57-33.67) \\
13\end{array}$ & $\begin{array}{l}5.04(0.61-42.04) \\
6\end{array}$ & $\begin{array}{l}2.64(0.24-29.27) \\
2\end{array}$ & $4.90(0.57-42.15)$ \\
\hline Emphysema & $\begin{array}{l}0.76(0.46-1.25) \\
53\end{array}$ & $\begin{array}{l}0.49(0.25-0.95) \\
14\end{array}$ & $\begin{array}{l}0.91(0.48-1.74) \\
16\end{array}$ & $\begin{array}{l}0.99(0.55-1.77) \\
23\end{array}$ \\
\hline Asthma & 0 unexp, 9 exp & 0 unexp, $3 \exp$ & o unexp, $4 \exp$ & 0 unexp, $2 \exp$ \\
\hline Cirrhosis & $\begin{array}{l}0.87(0.43-1.73) \\
31\end{array}$ & $\begin{array}{l}0.56(0.23-1.40) \\
8\end{array}$ & $\begin{array}{l}1.07(0.45-2.53) \\
10\end{array}$ & $\begin{array}{l}1.06(0.48-2.38) \\
13\end{array}$ \\
\hline $\begin{array}{l}\text { Motor Vehicle } \\
\text { Accident }\end{array}$ & $\begin{array}{l}0.83(0.50-1.37) \\
56\end{array}$ & $\begin{array}{l}0.52(0.27-1.03) \\
14\end{array}$ & $\begin{array}{l}1.25(0.68-2.27) \\
22\end{array}$ & $\begin{array}{l}0.86(0.47-1.59) \\
20\end{array}$ \\
\hline
\end{tabular}




\begin{tabular}{|l|l|l|l|l|}
\hline Cause of death $^{*}$ & All & 0-5 Unit Years & 5-25 Unit Years & 25 Unit Years \\
\hline Suicide & $1.03(0.62-1.72)$ & $1.17(0.66-2.10)$ & $1.08(0.56-2.08)$ & $0.82(0.42-1.57)$ \\
& 63 & 29 & 17 \\
\hline
\end{tabular}

Cox regression model: time variable $=$ age , covariate $=$ race

Referent group for all models: male workers with no chemical exposure $(n=1,836)$

A "-"indicates the hazard ratio cannot be calculated due to empty cell(s)

* Cause of death is malignant neoplasm unless otherwise specified 


\section{Table 3}

Hazard ratios (95\% confidence intervals) and numbers of cases for selected causes of death among female workers, by tertile of trichloroethylene cumulative exposure score

\begin{tabular}{|c|c|c|c|c|}
\hline Cause of death ${ }^{*}$ & All & 0-5 Unit Years & 5-25 Unit Years & $>25$ Unit Years \\
\hline All causes & $\begin{array}{l}0.99(0.89-1.09) \\
692\end{array}$ & $\begin{array}{l}1.04(0.90-1.19) \\
255\end{array}$ & $\begin{array}{l}0.84(0.67-1.04) \\
88\end{array}$ & \begin{tabular}{|l|}
$1.00(0.88-1.13)$ \\
349
\end{tabular} \\
\hline All cancer & $\begin{array}{l}0.93(0.74-1.16) \\
125 \\
\end{array}$ & $\begin{array}{l}1.06(0.78-1.45) \\
51\end{array}$ & $\begin{array}{l}0.82(0.49-1.36) \\
16\end{array}$ & \begin{tabular}{|l|}
$0.86(0.64-1.16)$ \\
58 \\
\end{tabular} \\
\hline $\begin{array}{l}\text { Buccal } \\
\text { cavity/pharynx }\end{array}$ & $1.08(0.18-6.47)$ & $\begin{array}{l}3.00(0.50-18.00) \\
2\end{array}$ & 0 & 0 \\
\hline Digestive organs & $\begin{array}{l}1.13(0.71-1.80) \\
32\end{array}$ & $\begin{array}{l}1.18(0.62-2.26) \\
12\end{array}$ & $\begin{array}{l}0.49(0.12-2.05) \\
2\end{array}$ & $\begin{array}{l}1.27(0.72-2.22) \\
18\end{array}$ \\
\hline Esophagus & $\begin{array}{l}2.81(0.25-31.10) \\
2\end{array}$ & $\begin{array}{l}3.99(0.25-63.94) \\
1\end{array}$ & $\begin{array}{l}9.59(0.60-154.14) \\
1\end{array}$ & 0 \\
\hline Stomach & \begin{tabular}{|l|}
$0.68(0.17-2.77)$ \\
3
\end{tabular} & $\begin{array}{l}1.27(0.25-6.35) \\
2\end{array}$ & 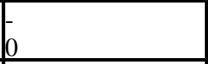 & \begin{tabular}{|l|}
$0.45(0.05-3.80)$ \\
1
\end{tabular} \\
\hline Colon & $\begin{array}{l}1.14(0.58-2.23) \\
16 \\
\end{array}$ & $\begin{array}{l}1.00(0.37-2.68) \\
5\end{array}$ & $\begin{array}{l}0.50(0.07-3.73) \\
1\end{array}$ & \begin{tabular}{|l|}
$1.43(0.66-3.09)$ \\
10 \\
\end{tabular} \\
\hline Rectum & $\begin{array}{l}0.87(0.08-9.59) \\
1\end{array}$ & 0 & 0 & $\begin{array}{l}1.76(0.16-19.47) \\
1\end{array}$ \\
\hline $\begin{array}{l}\text { Biliary } \\
\text { passage/liver }\end{array}$ & $\begin{array}{l}0.74(0.18-2.97) \\
3\end{array}$ & $\begin{array}{l}0.69(0.08-5.74) \\
1\end{array}$ & 0 & $\begin{array}{l}0.98(0.20-4.90) \\
2\end{array}$ \\
\hline Primary liver & 0 & - & 0 & - \\
\hline Pancreas & $1.71(0.57-5.12)$ & $2.06(0.51-8.26)$ & - & $\begin{array}{l}1.96(0.55-6.97) \\
4\end{array}$ \\
\hline Lung & $\begin{array}{l}0.53(0.27-1.07) \\
11 \\
\end{array}$ & $\begin{array}{l}0.69(0.27-1.77) \\
5\end{array}$ & $\begin{array}{l}0.65(0.16-2.73) \\
2\end{array}$ & $\begin{array}{l}0.39(0.14-1.11) \\
4\end{array}$ \\
\hline Breast & $\begin{array}{l}1.23(0.73-2.06) \\
26\end{array}$ & $\begin{array}{l}1.57(0.81-3.04) \\
12\end{array}$ & $\begin{array}{l}1.01(0.31-3.30) \\
3\end{array}$ & $\begin{array}{l}1.05(0.53-2.07) \\
11\end{array}$ \\
\hline Cervix & $\begin{array}{l}1.67(0.54-5.22) \\
6\end{array}$ & $\begin{array}{l}0.76(0.09-6.35) \\
1\end{array}$ & - & $\begin{array}{l}2.83(0.86-9.33) \\
5\end{array}$ \\
\hline \multicolumn{5}{|l|}{ Prostate } \\
\hline Kidney & $\begin{array}{l}0.93(0.15-5.76) \\
2\end{array}$ & 0 & $\begin{array}{l}2.86(0.27-29.85) \\
1\end{array}$ & $\begin{array}{l}0.97(0.10-9.50) \\
1 \\
\end{array}$ \\
\hline Bladder & $\begin{array}{l}0.22(0.03-1.83) \\
1\end{array}$ & 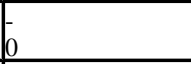 & 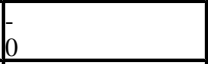 & \begin{tabular}{|l|}
$0.44(0.05-3.63)$ \\
1
\end{tabular} \\
\hline Melanoma of skin & $\begin{array}{l}1.67(0.23-11.86) \\
2\end{array}$ & $\begin{array}{l}2.29(0.21-25.25) \\
1\end{array}$ & 0 & $\begin{array}{l}1.68(0.15-18.60) \\
1\end{array}$ \\
\hline $\begin{array}{l}\text { Central Nerv. } \\
\text { System }\end{array}$ & 0 & $\begin{array}{l}- \\
0 \\
\end{array}$ & 0 & $\begin{array}{ll} \\
0 \\
\end{array}$ \\
\hline Endocrine & $\begin{array}{l}1.15(0.07-18.49) \\
1\end{array}$ & 0 & 0 & $\begin{array}{l}2.35(0.15-37.80) \\
1\end{array}$ \\
\hline Bone & $\begin{array}{l}1.37(0.09-22.12) \\
1\end{array}$ & $\overline{0}$ & $\begin{array}{l}9.44(0.58-153.20) \\
1\end{array}$ & \begin{tabular}{|l|} 
\\
0 \\
\end{tabular} \\
\hline $\begin{array}{l}\text { Lymphatic or } \\
\text { haemat. }\end{array}$ & $\begin{array}{l}1.00(0.55-1.83) \\
18\end{array}$ & $1.10(0.48-2.54)$ & $\begin{array}{l}0.38(0.05-2.79) \\
1\end{array}$ & $\begin{array}{l}1.11(0.53-2.31) \\
10\end{array}$ \\
\hline Hodgkin's Disease & 0 & $\begin{array}{ll} \\
0 \\
\end{array}$ & - & $\begin{array}{ll} \\
0 \\
\end{array}$ \\
\hline $\begin{array}{l}\text { Non-Hodgkin's } \\
\text { Lymph. }\end{array}$ & $\begin{array}{l}1.18(0.49-2.85) \\
9\end{array}$ & $\begin{array}{l}1.48(0.47-4.66) \\
4\end{array}$ & 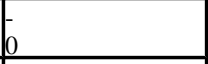 & $\begin{array}{l}1.30(0.45-3.77) \\
5\end{array}$ \\
\hline Multiple myeloma & $\begin{array}{l}2.37(0.67-8.44) \\
6\end{array}$ & $\begin{array}{l}2.20(0.40-12.02) \\
2\end{array}$ & $\begin{array}{l}2.79(0.31-25.05) \\
1\end{array}$ & $\begin{array}{l}2.38(0.53-10.67) \\
3\end{array}$ \\
\hline Leukemia & $\begin{array}{l}0.36(0.10-1.32) \\
3\end{array}$ & $\begin{array}{l}0.35(0.05-2.72) \\
1\end{array}$ & 0 & $\begin{array}{l}0.48(0.10-2.19) \\
2\end{array}$ \\
\hline $\begin{array}{l}\text { Ischemic Heart } \\
\text { Disease }\end{array}$ & $\begin{array}{l}1.07(0.87-1.32) \\
164\end{array}$ & $\begin{array}{l}1.17(0.88-1.56) \\
63\end{array}$ & $\begin{array}{l}0.70(0.42-1.62) \\
16\end{array}$ & $\begin{array}{l}1.11(0.86-1.44) \\
85\end{array}$ \\
\hline Diabetes & $\begin{array}{l}1.64(0.96-2.78) \\
31\end{array}$ & $\begin{array}{l}2.50(1.35-4.66) \\
17\end{array}$ & $\begin{array}{l}1.12(0.34-3.71) \\
3\end{array}$ & $\begin{array}{l}1.16(0.57-2.37) \\
11\end{array}$ \\
\hline $\begin{array}{l}\text { Cerebrovascular } \\
\text { Dis. }\end{array}$ & $\begin{array}{l}1.14(0.82-1.58) \\
71\end{array}$ & $\begin{array}{l}0.84(0.50-1.41) \\
18\end{array}$ & $\begin{array}{l}1.23(0.67-2.28) \\
12\end{array}$ & $\begin{array}{l}1.32(0.90-1.94) \\
41\end{array}$ \\
\hline $\begin{array}{l}\text { Non-Mal. Resp. } \\
\text { Dis. } \\
\end{array}$ & \begin{tabular}{|l|}
$0.80(0.57-1.14)$ \\
53
\end{tabular} & $\begin{array}{l}0.72(0.43-1.21) \\
17\end{array}$ & $\begin{array}{l}0.81(0.39-1.68) \\
8\end{array}$ & \begin{tabular}{|l|}
$0.86(0.56-1.32)$ \\
28 \\
\end{tabular} \\
\hline Bronchitis & $\begin{array}{l}2.67(0.24-29.64) \\
2\end{array}$ & $\begin{array}{l}3.81(0.24-61.10) \\
1\end{array}$ & 0 & $\begin{array}{l}2.66(0.17-42.72) \\
1\end{array}$ \\
\hline Emphysema & $\begin{array}{l}2.01(0.57-7.17) \\
6 \\
\end{array}$ & $\begin{array}{l}0.96(0.11-8.63) \\
1\end{array}$ & 0 & \begin{tabular}{|l|}
$3.33(0.89-12.48)$ \\
5
\end{tabular} \\
\hline Asthma & $\begin{array}{l}0.39(0.08-1.87) \\
2\end{array}$ & $1.05(0.22-5.10)$ & 0 & 0 \\
\hline Cirrhosis & $1.79(0.54-5.93) 6$ & $3.30(0.88-12.41)$ & $\begin{array}{l}2.20(0.26-18.89) \\
1\end{array}$ & $\begin{array}{l}0.59(0.07-5.10) \\
1\end{array}$ \\
\hline
\end{tabular}




\begin{tabular}{|l|l|l|l|l|}
\hline Cause of death $^{*}$ & All & $\mathbf{0 - 5}$ Unit Years & 5-25 Unit Years & >25 Unit Years \\
\hline Motor Vehicle & $1.50(0.62-3.63)$ & $1.65(0.51-5.28)$ & $1.08(0.14-8.48)$ & $1.51(0.51-4.43)$ \\
Accident & 10 & 4 & 1 & 5 \\
\hline Suicide & $1.28(0.41-4.04)$ & - & $1.85(0.23-15.07)$ & $2.08(0.61-7.12)$ \\
& 5 & 0 & 1 & 4 \\
\hline
\end{tabular}

Cox regression model: time variable $=$ age, covariate $=$ race

Referent group for all models: female workers with no chemical exposure $(n=1,983)$

A "-"indicates the hazard ratio cannot be calculated due to empty cell(s)

* Cause of death is malignant neoplasm unless otherwise specified 
Table 4

Hazard ratios (95\% confidence intervals) and numbers of cases for selected causes of death among male workers, by category of trichloroethylene exposure

\begin{tabular}{|c|c|c|c|c|}
\hline Cause of death ${ }^{*}$ & Low, intermittent & Low, continuous & Peak, infrequent & Peak, frequent \\
\hline All causes & $\begin{array}{l}0.99(0.92-1.06) \\
2499\end{array}$ & $\begin{array}{l}1.07(0.99-1.15) \\
1780\end{array}$ & $\begin{array}{l}1.05(0.95-1.16) \\
576\end{array}$ & $\begin{array}{l}1.08(1.01-1.17) \\
1649\end{array}$ \\
\hline All cancer & $\begin{array}{l}1.11(0.95-1.31) \\
529\end{array}$ & $\begin{array}{l}1.19(1.00-1.40) \\
372\end{array}$ & $\begin{array}{l}1.11(0.89-1.40) \\
113\end{array}$ & $\begin{array}{l}1.11(0.94-1.33) \\
317\end{array}$ \\
\hline $\begin{array}{l}\text { Buccal } \\
\text { cavity/pharynx }\end{array}$ & $1.07(0.28-4.18)$ & $\begin{array}{l}1.43(0.36-5.76) \\
6\end{array}$ & 0 & $1.22(0.29-5.11)$ \\
\hline Digestive organs & $\begin{array}{l}1.17(0.86-1.57) \\
155\end{array}$ & $\begin{array}{l}1.11(0.80-1.53) \\
97\end{array}$ & $\begin{array}{l}1.08(0.70-1.67) \\
31\end{array}$ & $1.12(0.80-1.55)$ \\
\hline Esophagus & $\begin{array}{l}1.92(0.55-6.73) \\
13\end{array}$ & $0.98(0.22-4.41)$ & $\begin{array}{l}2.15(0.43-10.69) \\
3\end{array}$ & $\begin{array}{l}1.59(0.40-6.41) \\
6\end{array}$ \\
\hline Stomach & $\begin{array}{l}0.70(0.36-1.37) \\
22\end{array}$ & $\begin{array}{l}0.82(0.40-1.67) \\
17\end{array}$ & $\begin{array}{l}0.15(0.02-1.14) \\
1\end{array}$ & $\begin{array}{l}0.68(0.32-1.46) \\
13\end{array}$ \\
\hline Colon & $\begin{array}{l}1.55(0.90-2.67) \\
57\end{array}$ & $\begin{array}{l}1.56(0.88-2.77) \\
38\end{array}$ & $\begin{array}{l}1.35(0.63-2.89) \\
11\end{array}$ & $\begin{array}{l}1.57(0.88-2.81) \\
35\end{array}$ \\
\hline Rectum & $\begin{array}{l}0.52(0.14-1.94) \\
5\end{array}$ & $\begin{array}{l}0.52(0.12-2.33) \\
3\end{array}$ & $\begin{array}{l}0.50(0.06-4.50) \\
1\end{array}$ & $0.57(0.13-2.56)$ \\
\hline $\begin{array}{l}\text { Biliary } \\
\text { passage/liver }\end{array}$ & $\begin{array}{l}1.79(0.78-4.12) \\
27\end{array}$ & $\begin{array}{l}1.51(0.61-3.73) \\
15\end{array}$ & $2.11(0.74-6.02)$ & $\begin{array}{l}1.29(0.51-3.28) \\
12\end{array}$ \\
\hline $\begin{array}{l}\text { Primary } \\
\text { liver }\end{array}$ & $\begin{array}{l}3.75(0.47-30.17) \\
8\end{array}$ & $\begin{array}{l}1.29(0.12-14.20) \\
2\end{array}$ & $\begin{array}{l}6.42(0.67-61.87) \\
3\end{array}$ & $\begin{array}{l}2.13(0.22-20.43 \\
3\end{array}$ \\
\hline Pancreas & $\begin{array}{l}0.86(0.45-1.64) \\
27\end{array}$ & $\begin{array}{l}0.88(0.44-1.77) \\
19\end{array}$ & $\begin{array}{l}1.18(0.49-2.80) \\
8\end{array}$ & $\begin{array}{l}0.96(0.48-1.93) \\
18\end{array}$ \\
\hline Lung & $\begin{array}{l}0.85(0.62-1.19) \\
105\end{array}$ & $\begin{array}{l}0.92(0.65-1.30) \\
75\end{array}$ & $\begin{array}{l}1.04(0.66-1.65) \\
27\end{array}$ & $\begin{array}{l}0.90(0.63-1.29) \\
67\end{array}$ \\
\hline \multicolumn{5}{|l|}{ Breast } \\
\hline \multicolumn{5}{|l|}{ Cervix } \\
\hline Prostate & $\begin{array}{l}1.22(0.82-1.82) \\
87\end{array}$ & $\begin{array}{l}1.30(0.85-1.99) \\
60\end{array}$ & $\begin{array}{l}1.02(0.57-1.86) \\
16\end{array}$ & $\begin{array}{l}1.24(0.81-1.92) \\
52\end{array}$ \\
\hline Kidney & $\begin{array}{l}1.58(0.52-4.76) \\
15\end{array}$ & $\begin{array}{l}1.79(0.57-5.62) \\
11\end{array}$ & $1.04(0.19-5.70)$ & $\begin{array}{l}1.11(0.31-3.96) \\
6\end{array}$ \\
\hline Bladder & $\begin{array}{l}1.03(0.44-2.41) \\
17\end{array}$ & $\begin{array}{l}1.32(0.55-3.18) \\
14\end{array}$ & $\begin{array}{l}0.59(0.12-2.78) \\
2\end{array}$ & $\begin{array}{l}0.82(0.30-2.19) \\
8\end{array}$ \\
\hline Melanoma of skin & $\begin{array}{l}0.63(0.20-1.99) \\
7\end{array}$ & $\begin{array}{l}0.56(0.15-2.09) \\
4\end{array}$ & $\begin{array}{l}0.90(0.17-4.63) \\
2\end{array}$ & $\begin{array}{l}0.76(0.22-2.64) \\
5\end{array}$ \\
\hline $\begin{array}{l}\text { Central Nerv. } \\
\text { System }\end{array}$ & $\begin{array}{l}0.92(0.28-2.98) \\
9\end{array}$ & $\begin{array}{l}1.37(0.42-4.46) \\
9\end{array}$ & $\begin{array}{l}3.00(0.85-10.64) \\
6\end{array}$ & $\begin{array}{l}0.88(0.24-3.26) \\
5\end{array}$ \\
\hline Endocrine & $\begin{array}{l}0.94(0.08-10.52) \\
2\end{array}$ & $\begin{array}{l}0.66(0.04-11.11) \\
1\end{array}$ & 0 & 0 \\
\hline Bone & 0 unexp, $4 \exp$ & 0 unexp, $3 \exp$ & 0 unexp, 1 exp & 0 unexp, $3 \exp$ \\
\hline $\begin{array}{l}\text { Lymphatic or } \\
\text { haemat. }\end{array}$ & $\begin{array}{l}1.08(0.68-1.71) \\
61\end{array}$ & $\begin{array}{l}1.39(0.86-2.23) \\
52\end{array}$ & $\begin{array}{l}1.39(0.76-2.57) \\
17\end{array}$ & $\begin{array}{l}1.24(0.76-2.03) \\
42\end{array}$ \\
\hline Hodgkin's Disease & $\begin{array}{l}0.82(0.07-9.00) \\
2\end{array}$ & $\begin{array}{l}1.77(0.18-17.01) \\
3\end{array}$ & $\begin{array}{l}2.00(0.13-31.98) \\
1\end{array}$ & $2.70(0.30-24.15$ \\
\hline $\begin{array}{l}\text { Non-Hodgkin's } \\
\text { Lymph. } \\
\end{array}$ & $\begin{array}{l}1.50(0.67-3.34) \\
25\end{array}$ & $\begin{array}{l}1.74(0.76-3.97) \\
20\end{array}$ & $1.90(0.69-5.24)$ & $\begin{array}{l}1.57(0.67-3.69) \\
16 \\
\end{array}$ \\
\hline Multiple myeloma & $\begin{array}{l}1.01(0.38-2.66) \\
13\end{array}$ & $\begin{array}{l}1.21(0.44-3.35) \\
10\end{array}$ & $\begin{array}{l}1.78(0.54-5.84) \\
5\end{array}$ & $\begin{array}{l}1.31(0.48-3.63) \\
10\end{array}$ \\
\hline Leukemia & $\begin{array}{l}0.89(0.42-1.91) \\
20\end{array}$ & $\begin{array}{l}1.11(0.50-2.45) \\
16\end{array}$ & $\begin{array}{l}0.63(0.17-2.30) \\
3\end{array}$ & $\begin{array}{l}0.69(0.28-1.69) \\
9\end{array}$ \\
\hline $\begin{array}{l}\text { Ischemic Heart } \\
\text { Disease }\end{array}$ & $1.03(0.90-1.16)$ & $\begin{array}{l}1.10(0.96-1.25) \\
545\end{array}$ & $\begin{array}{l}1.12(0.93-1.33) \\
182\end{array}$ & $\begin{array}{l}1.14(0.99-1.31) \\
516\end{array}$ \\
\hline Diabetes & $\begin{array}{l}1.08(0.70-1.67) \\
67\end{array}$ & $\begin{array}{l}0.98(0.61-1.58) \\
41\end{array}$ & $\begin{array}{l}1.23(0.68-2.22) \\
17\end{array}$ & $\begin{array}{l}1.09(0.68-1.74) \\
42\end{array}$ \\
\hline $\begin{array}{l}\text { Cerebrovascular } \\
\text { Dis. }\end{array}$ & $\begin{array}{l}0.88(0.67-1.14) \\
148\end{array}$ & $\begin{array}{l}0.97(0.73-1.92) \\
109\end{array}$ & $\begin{array}{l}0.98(0.67-1.44) \\
38\end{array}$ & $\begin{array}{l}1.06(0.80-1.41) \\
112\end{array}$ \\
\hline $\begin{array}{l}\text { Non-Mal. Resp. } \\
\text { Dis. }\end{array}$ & $\begin{array}{l}1.14(0.90-1.45) \\
224\end{array}$ & $\begin{array}{l}1.53(1.20-1.96) \\
198 \\
\end{array}$ & $\begin{array}{l}1.27(0.91-1.77) \\
55\end{array}$ & $\begin{array}{l}1.44(1.12-1.85) \\
171\end{array}$ \\
\hline Bronchitis & $\begin{array}{l}3.22(0.39-26.36) \\
7\end{array}$ & $\begin{array}{l}6.34(0.80-50.33) \\
9 \\
\end{array}$ & $\begin{array}{l}2.19(0.14-35.04) \\
1\end{array}$ & $\begin{array}{l}4.95(0.59-41.27 \\
6\end{array}$ \\
\hline Emphysema & $\begin{array}{l}0.63(0.37-1.08) \\
32\end{array}$ & $\begin{array}{l}0.94(0.54-1.61) \\
32\end{array}$ & $\begin{array}{l}0.86(0.40-1.87) \\
9\end{array}$ & $\begin{array}{l}0.94(0.53-1.64) \\
28\end{array}$ \\
\hline Asthma & 0 unexp, 3 exp & 0 unexp, 4 exp & 0 unexp, 2 exp & 0 unexp, 4 exp \\
\hline Cirrhosis & $\begin{array}{l}0.85(0.41-1.74) \\
22\end{array}$ & $\begin{array}{l}0.95(0.45-2.04) \\
17 \\
\end{array}$ & $1.14(0.42-3.09)$ & $\begin{array}{l}0.96(0.44-2.08) \\
15\end{array}$ \\
\hline $\begin{array}{l}\text { Motor Vehicle } \\
\text { Accident }\end{array}$ & $\begin{array}{l}0.64(0.36-1.11) \\
30\end{array}$ & $\begin{array}{l}0.82(0.46-1.44) \\
28\end{array}$ & $\begin{array}{l}0.60(0.24-1.48) \\
6\end{array}$ & $\begin{array}{l}1.05(0.61-1.83) \\
32\end{array}$ \\
\hline
\end{tabular}


Cause of death $^{*}$ Low, intermittent Low, continuous Peak, infrequent Peak, frequent

\begin{tabular}{|l|l|l|l|l|}
\hline Suicide & $0.99(0.58-1.70)$ & $1.09(0.62-1.91)$ & $0.76(0.32-1.80)$ & $0.82(0.44-1.51)$ \\
\hline
\end{tabular}

Cox regression model: time variable $=$ age , covariate $=$ race

Referent group for all models: male workers with no chemical exposure $(n=1,836)$

A “-”indicates the hazard ratio cannot be calculated due to empty cell(s)

* Cause of death is malignant neoplasm unless otherwise specified 


\section{Table 5}

Hazard ratios (95\% confidence intervals) and numbers of cases for selected causes of death among female workers, by category of trichloroethylene exposure

\begin{tabular}{|c|c|c|c|c|}
\hline Cause of death ${ }^{*}$ & Low, intermittent & Low, continuous & Peak, infrequent & Peak, frequent \\
\hline All causes & $\begin{array}{l}1.03(0.90-1.16) \\
335\end{array}$ & $\begin{array}{l}0.90(0.76-1.06) \\
167\end{array}$ & $\begin{array}{l}0.94(0.73-1.20) \\
68\end{array}$ & $\begin{array}{l}0.99(0.89-1.12) \\
423\end{array}$ \\
\hline All cancer & $\begin{array}{l}1.17(0.89-1.53) \\
73\end{array}$ & $\begin{array}{l}0.91(0.62-1.34) \\
30\end{array}$ & $\begin{array}{l}1.30(0.82-2.06) \\
20\end{array}$ & $\begin{array}{l}0.85(0.64-1.12) \\
69\end{array}$ \\
\hline $\begin{array}{l}\text { Buccal } \\
\text { cavity/pharynx }\end{array}$ & $2.38(0.40-14.29)$ & 0 & 0 & 0 \\
\hline Digestive organs & $\begin{array}{l}1.20(0.67-2.15) \\
16\end{array}$ & $\begin{array}{l}0.57(0.20-1.61) \\
4\end{array}$ & $1.87(0.79-4.41)$ & $\begin{array}{l}1.13(0.65-1.96) \\
19\end{array}$ \\
\hline Esophagus & $\begin{array}{l}3.30(0.21-52.85) \\
1\end{array}$ & 0 & $\begin{array}{l}12.83(0.80- \\
205.19) 1 \\
\end{array}$ & $\begin{array}{l}2.26(0.14-36.36) \\
1\end{array}$ \\
\hline Stomach & $\begin{array}{l}0.95(0.19-4.78) \\
2\end{array}$ & $\begin{array}{l}0.93(0.11-7.80) \\
1\end{array}$ & 0 & $\begin{array}{l}0.42(0.05-3.46) \\
1\end{array}$ \\
\hline Colon & $1.22(0.53-2.82)$ & $\begin{array}{l}0.90(0.26-3.08) \\
3\end{array}$ & $\begin{array}{l}1.28(0.30-5.53) \\
2\end{array}$ & $\begin{array}{l}1.21(0.56-2.63) \\
10\end{array}$ \\
\hline Rectum & 0 & 0 & $\begin{array}{l}6.51(0.59-71.81) \\
1\end{array}$ & $\begin{array}{l}1.44(0.13-15.89) \\
1\end{array}$ \\
\hline $\begin{array}{l}\text { Biliary } \\
\text { passage/liver }\end{array}$ & $1.06(0.21-5.27)$ & 0 & $\begin{array}{l}4.30(0.87-21.33) \\
2\end{array}$ & $\begin{array}{l}0.82(0.17-4.09) \\
2\end{array}$ \\
\hline Primary liver & 0 & 0 & - & 0 \\
\hline Pancreas & $1.53(0.38-6.13)$ & 0 & 0 & $1.59(0.45-5.65)$ \\
\hline Lung & $\begin{array}{l}0.73(0.32-1.66) \\
7\end{array}$ & $\begin{array}{l}1.04(0.40-2.70) \\
5\end{array}$ & $\begin{array}{l}0.43(0.06-3.12) \\
1\end{array}$ & $\begin{array}{l}0.41(0.16-1.07) \\
5\end{array}$ \\
\hline Breast & $\begin{array}{l}1.92(1.08-3.43) \\
18\end{array}$ & $\begin{array}{l}1.71(0.79-3.71) \\
8\end{array}$ & $\begin{array}{l}1.18(0.36-3.86) \\
3\end{array}$ & $\begin{array}{l}1.08(0.57-2.02) \\
14\end{array}$ \\
\hline Cervix & $\begin{array}{l}1.75(0.43-7.05) \\
3\end{array}$ & $\begin{array}{l}1.05(0.13-8.87) \\
1\end{array}$ & $\begin{array}{l}4.41(0.89-21.86) \\
2\end{array}$ & $\begin{array}{l}2.30(0.70-7.58) \\
5\end{array}$ \\
\hline \multicolumn{5}{|l|}{ Prostate } \\
\hline Kidney & 0 & 0 & 0 & $\begin{array}{l}1.50(0.24-9.40) \\
2\end{array}$ \\
\hline Bladder & 0 & 0 & 0 & $\begin{array}{l}0.36(0.04-3.02) \\
1\end{array}$ \\
\hline Melanoma of skin & 0 & 0 & $\begin{array}{l}6.73(0.61-74.20) \\
1 \\
\end{array}$ & $\begin{array}{l}1.42(0.13-15.72) \\
1\end{array}$ \\
\hline $\begin{array}{l}\text { Central Nerv. } \\
\text { System }\end{array}$ & 0 & 0 & 0 & 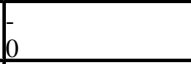 \\
\hline Endocrine & 0 & 0 & 0 & $\begin{array}{l}1.95(0.12-31.35) \\
1\end{array}$ \\
\hline Bone & $\begin{array}{l}2.97(0.18-48.05) \\
1\end{array}$ & $\begin{array}{l}5.44(0.33-89.27) \\
1\end{array}$ & 0 & 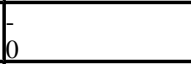 \\
\hline $\begin{array}{l}\text { Lymphatic or } \\
\text { haemat. }\end{array}$ & $\begin{array}{l}1.32(0.65-2.69) \\
11\end{array}$ & $\begin{array}{l}0.65(0.20-2.18) \\
3\end{array}$ & $\begin{array}{l}1.98(0.69-5.68) \\
4\end{array}$ & $\begin{array}{l}0.97(0.48-1.98) \\
11\end{array}$ \\
\hline Hodgkin's Disease & 0 & 0 & 0 & 0 \\
\hline $\begin{array}{l}\text { Non-Hodgkin's } \\
\text { Lymph. } \\
\end{array}$ & $\begin{array}{l}1.39(0.48-4.03) \\
5\end{array}$ & $\begin{array}{l}1.03(0.23-4.68) \\
2\end{array}$ & $\begin{array}{l}3.45(0.96-12.37) \\
3\end{array}$ & $\begin{array}{l}1.27(0.47-3.45) \\
6\end{array}$ \\
\hline Multiple myeloma & $4.26(1.14-15.92)$ & $\begin{array}{l}1.71(0.19-15.43) \\
1\end{array}$ & $\begin{array}{l}3.20(0.36-28.69) \\
1\end{array}$ & $\begin{array}{l}1.93(0.43-8.65) \\
3\end{array}$ \\
\hline Leukemia & $\begin{array}{l}0.27(0.03-2.09) \\
1\end{array}$ & 0 & 0 & $\begin{array}{l}0.38(0.08-1.75) \\
2\end{array}$ \\
\hline $\begin{array}{l}\text { Ischemic Heart } \\
\text { Disease }\end{array}$ & $\begin{array}{l}0.95(0.72-1.25) \\
69\end{array}$ & $\begin{array}{l}0.90(0.63-1.29) \\
37\end{array}$ & $\begin{array}{l}1.25(0.79-1.98) \\
20\end{array}$ & $\begin{array}{l}1.08(0.84-1.37) \\
99\end{array}$ \\
\hline Diabetes & $\begin{array}{l}1.91(1.03-3.53) \\
18\end{array}$ & $\begin{array}{l}0.60(0.18-2.00) \\
3\end{array}$ & $\begin{array}{l}0.47(0.06-3.45) \\
1\end{array}$ & $\begin{array}{l}1.24(0.64-2.40) \\
14\end{array}$ \\
\hline $\begin{array}{l}\text { Cerebrovascular } \\
\text { Dis. }\end{array}$ & $\begin{array}{l}0.95(0.61-1.47) \\
28\end{array}$ & $\begin{array}{l}1.47(0.92-2.35) \\
24\end{array}$ & $\begin{array}{l}0.83(0.34-2.07) \\
5\end{array}$ & $\begin{array}{l}1.50(1.05-2.13) \\
55\end{array}$ \\
\hline $\begin{array}{l}\text { Non-Mal. Resp. } \\
\text { Dis. }\end{array}$ & $\begin{array}{l}0.87(0.56-1.35) \\
27\end{array}$ & $\begin{array}{l}0.80(0.45-1.42) \\
14\end{array}$ & $\begin{array}{l}0.63(0.23-1.71) \\
4\end{array}$ & $\begin{array}{l}0.87(0.58-1.30) \\
34\end{array}$ \\
\hline Bronchitis & $\begin{array}{l}3.11(0.19-50.14) \\
1\end{array}$ & \begin{tabular}{|l}
$5.47(0.33-90.07)$ \\
1
\end{tabular} & 0 & $\begin{array}{l}2.29(0.14-36.93) \\
1\end{array}$ \\
\hline Emphysema & $\begin{array}{l}0.74(0.08-6.64) \\
1\end{array}$ & $\begin{array}{l}1.34(0.15-12.07) \\
1\end{array}$ & 0 & $2.77(0.74-10.37)$ \\
\hline Asthma & $\begin{array}{l}0.82(0.17-3.99) \\
2\end{array}$ & 0 & 0 & 0 \\
\hline Cirrhosis & $2.57(0.68-9.74)$ & 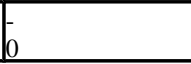 & 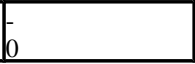 & $\begin{array}{l}0.90(0.17-4.72) \\
2\end{array}$ \\
\hline
\end{tabular}




\begin{tabular}{|l|l|l|l|l|}
\hline Cause of death $^{*}$ & Low, intermittent & Low, continuous & Peak, infrequent & Peak, frequent \\
\hline Motor Vehicle & $1.96(0.71-5.46)$ & & - & $1.47(0.53-4.09)$ \\
Accident & 6 & 0 & 0 & 6 \\
\hline Suicide & 0 & 0 & $1.94(0.24-15.75)$ & $2.12(0.67-6.69)$ \\
& 0 & 1 & 5 \\
\hline
\end{tabular}

Cox regression model: time variable $=$ age , covariate $=$ race

Referent group for all models: female workers with no chemical exposure $(n=1,983)$

A "-"indicates the hazard ratio cannot be calculated due to empty cell(s)

* Cause of death is malignant neoplasm unless otherwise specified 


\section{Table 6}

Hazard ratios ( $95 \%$ confidence intervals) and numbers of cases for mortality from breast cancer among female workers with exposure to chemicals

\begin{tabular}{|c|c|c|}
\hline Chemical & Hazard ratio $(95 \% \mathrm{CI})$ & No. exposed cases \\
\hline \begin{tabular}{|l|} 
Any solvent \\
\end{tabular} & $1.19(0.75-1.91)$ & 38 \\
\hline 1,1,1-trichloroethane & $2.35(0.83-6.64)$ & 4 \\
\hline Acetone & $1.19(0.55-2.59)$ & 8 \\
\hline Carbon tetrachloride & $1.06(0.63-1.77)$ & 26 \\
\hline Chloroform & - & 0 \\
\hline Freon & $2.71(1.33-5.50)$ & 10 \\
\hline Isopropyl alcohol & $2.64(1.30-5.35)$ & 10 \\
\hline IP4 gasoline & $1.06(0.51-2.21)$ & 9 \\
\hline Metal fumes/dust & $1.77(0.42-7.37)$ & 2 \\
\hline Methylene chloride & $2.35(0.98-5.65)$ & 6 \\
\hline Methylethyl ketone & $1.61(0.81-3.20)$ & 11 \\
\hline Nitroglycerine & - & 0 \\
\hline O-dichlorobenzene & $0.64(0.09-4.74)$ & 1 \\
\hline Other alcohols & $1.57(0.38-6.55)$ & 2 \\
\hline Perchloroethylene & $0.48(0.07-3.50)$ & 1 \\
\hline Silica & & 0 \\
\hline Solder flux & $2.76(1.32-5.76)$ & 9 \\
\hline Stoddard solvent & $1.03(0.60-1.76)$ & 23 \\
\hline Styrene & $1.30(0.18-9.54)$ & 1 \\
\hline Toluene & $1.44(0.76-2.74)$ & 13 \\
\hline Xylene & - & 0 \\
\hline Zinc chromate & $1.18(0.58-2.40)$ & 10 \\
\hline
\end{tabular}

Cox regression model: time variable $=$ age, covariate $=$ race

Referent group for all models: female workers with no chemical exposure $(n=1,983)$

A “-”indicates the hazard ratio cannot be calculated due to empty cell(s) 
Table 7

Hazard ratios (95\% confidence intervals) and numbers of cases for mortality from non-Hodgkin's lymphoma among male and female workers with exposure to chemicals

\begin{tabular}{|c|c|c|c|c|}
\hline \multirow[b]{2}{*}{ Chemical } & \multicolumn{2}{|l|}{ Men } & \multicolumn{2}{|c|}{ Women } \\
\hline & Hazard ratio $(95 \% \mathrm{CI})$ & No. exposed cases & Hazard ratio $(95 \% \mathrm{CI})$ & No. exposed cases \\
\hline Any solvent & \begin{tabular}{|l|}
$1.48(0.70-3.12)$ \\
\end{tabular} & \begin{tabular}{|c|}
50 \\
\end{tabular} & \begin{tabular}{|l|}
$1.07(0.47-2.44)$ \\
\end{tabular} & \begin{tabular}{|c|}
12 \\
\end{tabular} \\
\hline 1,1,1-trichloroethane & $1.51(0.61-3.73)$ & 12 & - & 0 \\
\hline Acetone & $1.49(0.58-3.82)$ & 10 & $0.73(0.16-3.32)$ & 2 \\
\hline Carbon tetrachloride & $1.38(0.63-3.04)$ & 28 & $1.16(0.49-2.74)$ & 10 \\
\hline Chloroform & - & 0 & - & 0 \\
\hline Freon & $1.96(0.83-4.68)$ & 15 & $2.25(0.63-8.09)$ & 3 \\
\hline Isopropyl alcohol & $2.00(0.83-4.83)$ & 14 & $2.14(0.60-7.69)$ & 3 \\
\hline JP4 gasoline & $1.71(0.74-3.95)$ & 19 & $0.70(0.16-3.15)$ & 2 \\
\hline Metal fumes/dust & $0.76(0.20-2.89)$ & 3 & - & 0 \\
\hline Methylene chloride & $2.02(0.76-5.42)$ & 8 & - & 0 \\
\hline Methylethyl ketone & $1.15(0.40-3.32)$ & 6 & $0.42(0.05-3.26)$ & 1 \\
\hline Nitroglycerine & - & 0 & - & 0 \\
\hline O-dichlorobenzene & $1.90(0.66-5.51)$ & 6 & $2.07(0.27-16.10)$ & 1 \\
\hline Other alcohols & $1.79(0.58-5.49)$ & 5 & - & 0 \\
\hline Perchloroethylene & $2.32(0.75-7.15)$ & 5 & $2.35(0.52-10.71)$ & 2 \\
\hline Silica & $2.71(0.34-21.81)$ & 1 & - & 0 \\
\hline Solder flux & $1.81(0.74-4.44)$ & 13 & $2.55(0.71-9.17)$ & 3 \\
\hline Stoddard solvent & $1.47(0.68-3.20)$ & 32 & $0.76(0.28-2.06)$ & 6 \\
\hline Styrene & - & 0 & - & 0 \\
\hline Toluene & $1.05(0.36-3.06)$ & 6 & $0.89(0.25-3.20)$ & 3 \\
\hline Xylene & $2.48(0.29-20.93)$ & 1 & - & 0 \\
\hline Zinc chromate & $1.34(0.52-3.50)$ & 9 & $1.01(0.28-3.63)$ & 3 \\
\hline
\end{tabular}

Cox regression model: time variable $=$ age, covariate $=$ race

Referent group for all models for males: male workers with no chemical exposure $(n=1,836)$

Referent group for all models for females: female workers with no chemical exposure $(n=1,983)$

A “-"indicates the hazard ratio cannot be calculated due to empty cell(s) 
Table 8

Hazard ratios (95\% confidence intervals) and numbers of cases for mortality from multiple myeloma among male and female workers with exposure to chemicals

\begin{tabular}{|c|c|c|c|c|}
\hline \multirow[b]{2}{*}{ Chemical } & \multicolumn{2}{|l|}{ Men } & \multicolumn{2}{|c|}{ Women } \\
\hline & Hazard ratio $(95 \% \mathrm{CI})$ & No. exposed cases & Hazard ratio $(95 \% \mathrm{CI})$ & No. exposed cases \\
\hline Any solvent & \begin{tabular}{|l|}
$1.20(0.50-2.89)$ \\
\end{tabular} & 30 & \begin{tabular}{|l|}
$2.09(0.63-6.96)$ \\
\end{tabular} & \begin{tabular}{|c|}
8 \\
\end{tabular} \\
\hline 1,1,1-trichloroethane & $0.64(0.18-2.30)$ & 4 & $14.46(3.24-64.63)$ & 3 \\
\hline Acetone & $0.98(0.30-3.24)$ & 5 & $2.41(0.44-13.24)$ & 2 \\
\hline Carbon tetrachloride & $1.29(0.51-3.25)$ & 19 & $2.03(0.57-7.19)$ & 6 \\
\hline Chloroform & - & 0 & - & 0 \\
\hline Freon & $2.02(0.74-5.50)$ & 11 & - & 0 \\
\hline Isopropyl alcohol & $1.11(0.35-3.47)$ & 6 & - & 0 \\
\hline JP4 gasoline & $1.29(0.47-3.53)$ & 11 & $1.98(0.36-10.82)$ & 2 \\
\hline Metal fumes/dust & $0.92(0.23-3.67)$ & 3 & - & 0 \\
\hline Methylene chloride & $2.58(0.86-7.72)$ & 7 & - & 0 \\
\hline Methylethyl ketone & $0.76(0.19-3.03)$ & 3 & $4.98(1.24-19.93)$ & 4 \\
\hline Nitroglycerine & - & 0 & - & 0 \\
\hline O-dichlorobenzene & $2.12(0.64-7.02)$ & 5 & $5.56(0.62-49.89)$ & 1 \\
\hline Other alcohols & $2.04(0.57-7.28)$ & 4 & - & 0 \\
\hline Perchloroethylene & $1.71(0.42-6.91)$ & 3 & $7.84(1.43-43.06)$ & 2 \\
\hline Silica & - & 0 & - & 0 \\
\hline Solder flux & $1.07(0.34-3.35)$ & 6 & - & 0 \\
\hline Stoddard solvent & $1.16(0.46-2.92)$ & 18 & $2.26(0.64-8.02)$ & 6 \\
\hline Styrene & - & 0 & - & 0 \\
\hline Toluene & $0.98(0.28-3.49)$ & 4 & $4.54(1.22-16.95)$ & 5 \\
\hline Xylene & - & 0 & - & 0 \\
\hline Zinc chromate & $1.16(0.37-3.63)$ & 6 & $3.94(0.98-15.79)$ & 4 \\
\hline
\end{tabular}

Cox regression model: time variable $=$ age, covariate $=$ race

Referent group for all models for males: male workers with no chemical exposure $(n=1,836)$

Referent group for all models for females: female workers with no chemical exposure $(n=1,983)$

A “-”indicates the hazard ratio cannot be calculated due to empty cell(s) 
Table 9

Hazard ratios (95\% confidence intervals) and numbers of cases for mortality from non-malignant respiratory diseases among male and female workers with exposure to chemicals

\begin{tabular}{|c|c|c|c|c|}
\hline \multirow[b]{2}{*}{ Chemical } & \multicolumn{2}{|l|}{ Men } & \multicolumn{2}{|c|}{ Women } \\
\hline & Hazard ratio $(95 \% \mathrm{CI})$ & No. exposed cases & Hazard ratio $(95 \% \mathrm{CI})$ & No. exposed cases \\
\hline Any solvent & \begin{tabular}{|l|}
$1.29(1.04-1.61)$ \\
\end{tabular} & 504 & \begin{tabular}{|l|}
$0.85(0.62-1.16)$ \\
\end{tabular} & \begin{tabular}{|l|}
79 \\
\end{tabular} \\
\hline 1,1,1-trichloroethane & $1.03(0.77-1.37)$ & 95 & $1.04(0.38-2.85)$ & 4 \\
\hline Acetone & $1.29(0.97-1.71)$ & 95 & $0.71(0.41-1.24)$ & 15 \\
\hline Carbon tetrachloride & $1.34(1.06-1.68)$ & 313 & $0.83(0.59-1.16)$ & 58 \\
\hline Chloroform & $1.28(0.70-2.34)$ & 12 & $1.25(0.17-8.96)$ & 1 \\
\hline Freon & $1.46(1.12-1.90)$ & 132 & $0.83(0.40-1.73)$ & 8 \\
\hline Isopropyl alcohol & $1.37(1.04-1.81)$ & 113 & $1.10(0.58-2.06)$ & 11 \\
\hline JP4 gasoline & $1.31(1.01-1.69)$ & 157 & $1.21(0.77-1.90)$ & 25 \\
\hline Metal fumes/dust & $0.97(0.68-1.37)$ & 47 & $0.61(0.15-2.48)$ & 2 \\
\hline Methylene chloride & $1.52(1.11-2.08)$ & 67 & $0.92(0.40-2.11)$ & 6 \\
\hline Methylethyl ketone & $1.42(1.06-1.90)$ & 86 & $0.80(0.46-1.42)$ & 14 \\
\hline Nitroglycerine & $0.61(0.19-1.92)$ & 3 & - & 0 \\
\hline O-dichlorobenzene & $1.73(1.25-2.38)$ & 62 & $0.62(0.15-2.53)$ & 2 \\
\hline Other alcohols & $1.33(0.92-1.91)$ & 42 & $2.06(0.95-4.47)$ & 7 \\
\hline Perchloroethylene & $1.83(1.28-2.60)$ & 46 & $0.51(0.19-1.41)$ & 4 \\
\hline Silica & $1.14(0.46-2.81)$ & 5 & - & 0 \\
\hline Solder flux & $1.30(0.98-1.71)$ & 110 & $0.85(0.39-1.85)$ & 7 \\
\hline Stoddard solvent & $1.35(1.07-1.69)$ & 335 & $0.83(0.58-1.18)$ & 51 \\
\hline Styrene & $1.21(0.56-2.61)$ & 7 & $0.47(0.07-3.38)$ & 1 \\
\hline Toluene & $1.38(1.03-1.84)$ & 86 & $0.79(0.48-1.28)$ & 20 \\
\hline Xylene & $1.03(0.38-2.80)$ & 4 & $0.77(0.11-5.60)$ & 1 \\
\hline Zinc chromate & $1.48(1.12-1.94)$ & 115 & $0.93(0.58-1.51)$ & 21 \\
\hline
\end{tabular}

Cox regression model: time variable $=$ age, covariate $=$ race

Referent group for all models for males: male workers with no chemical exposure $(n=1,836)$

Referent group for all models for females: female workers with no chemical exposure $(n=1,983)$

A “-”indicates the hazard ratio cannot be calculated due to empty cell(s) 


\section{Table 10}

Hazard ratios (95\% confidence intervals) and numbers of cases for mortality from various causes among male and female workers with exposure to chemicals: summary of other statistically significant associations

\begin{tabular}{|c|c|c|c|c|}
\hline \multirow[b]{2}{*}{ Chemical/cause of death ${ }^{*}$} & \multicolumn{2}{|c|}{\begin{tabular}{|c|} 
Men \\
\end{tabular}} & \multicolumn{2}{|c|}{ Women } \\
\hline & Hazard ratio (95\% CI) & No. exposed cases & Hazard ratio $(95 \% \mathrm{CI})$ & No. exposed cases \\
\hline \multicolumn{5}{|l|}{ Any solvent } \\
\hline All causes & $1.06(1.00-1.13)$ & 5242 & & \\
\hline Diabetes & & & $1.64(1.00-2.68)$ & 45 \\
\hline \multicolumn{5}{|l|}{ 1,1,1-trichloroethane } \\
\hline Bone & & & $17.87(1.12-286)$ & 1 \\
\hline \multicolumn{5}{|l|}{ Acetone } \\
\hline Prostate & $1.59(1.01-2.51)$ & 41 & & \\
\hline Ischemic heart disease & $1.17(1.01-1.36)$ & 341 & & \\
\hline \multicolumn{5}{|l|}{ Carbon tetrachloride } \\
\hline \begin{tabular}{|l|l|} 
All causes \\
\end{tabular} & $1.07(1.00-1.14)$ & 3182 & & \\
\hline \multicolumn{5}{|l|}{ Freon } \\
\hline Lymphatic/haematopoietic & $1.64(1.00-2.68)$ & 42 & & \\
\hline \multicolumn{5}{|l|}{ IP4 gasoline } \\
\hline All cancers & $1.21(1.02-1.43)$ & 375 & & \\
\hline Pancreas & & & $3.31(1.01-10.84)$ & 5 \\
\hline Emphysema & & & $3.99(1.00-15.96)$ & 4 \\
\hline \multicolumn{5}{|l|}{ Methylene chloride } \\
\hline Bronchitis & $9.21(1.03-82.69)$ & 4 & & \\
\hline \multicolumn{5}{|l|}{ O-dichlorobenzene } \\
\hline All causes & $1.14(1.03-1.27)$ & 534 & $1.32(1.00-1.76)$ & 51 \\
\hline All cancers & $1.28(1.01-1.60)$ & 112 & & \\
\hline Lymphatic/haematopoietic & $1.82(1.00-3.30)$ & 19 & & \\
\hline Esophagus & & & $21.07(1.32-337)$ & 1 \\
\hline Pancreas & & & $7.89(1.58-39.34)$ & 2 \\
\hline \multicolumn{5}{|l|}{ Other alcohols } \\
\hline Bone & & & $24.86(1.56-397)$ & 1 \\
\hline \multicolumn{5}{|l|}{ Perchloroethylene } \\
\hline All causes & $1.17(1.04-1.31)$ & 382 & & \\
\hline Lymphatic/haematopoietic & $1.92(1.00-3.69)$ & 14 & & \\
\hline Cerebrovascular disease & $1.59(1.07-2.35)$ & 36 & & \\
\hline Motor vehicle accident & & & $4.40(1.19-16.24)$ & 3 \\
\hline \multicolumn{5}{|l|}{ Silica } \\
\hline All causes & $1.32(1.04-1.66)$ & 77 & $2.96(1.10-8.01)$ & 4 \\
\hline Ischemic heart disease & $1.50(1.00-2.24)$ & 26 & & \\
\hline \multicolumn{5}{|l|}{ Solder flux } \\
\hline All cancers & & & $1.51(1.03-2.22)$ & 30 \\
\hline \multicolumn{5}{|l|}{ Stoddard solvent } \\
\hline All causes & $1.07(1.00-1.14)$ & 3378 & & \\
\hline \multicolumn{5}{|l|}{ Styrene } \\
\hline Rectum & $6.93(1.27-37.84)$ & 2 & & \\
\hline \multicolumn{5}{|l|}{ Toluene } \\
\hline All causes & $1.09(1.00-1.19)$ & 882 & & \\
\hline \multicolumn{5}{|l|}{ Xylene } \\
\hline Central Nervous System & $12.09(2.21-65.99)$ & 2 & & \\
\hline \multirow{2}{*}{\multicolumn{5}{|c|}{$\begin{array}{l}\text { Zinc chromate } \\
\text { All causes }\end{array}$}} \\
\hline & $1.11(1.02-1.21)$ & 1119 & & \\
\hline
\end{tabular}

Cox regression model: time variable $=$ age, covariate $=$ race

Referent group for all models for males: male workers with no chemical exposure $(n=1,836)$

Referent group for all models for females: female workers with no chemical exposure $(n=1,983)$

Cause of death is malignant neoplasm unless otherwise specified 